\title{
Saharan and Asian dust: similarities and differences determined by CALIPSO, AERONET, and a coupled climate-aerosol microphysical model
}

\author{
L. Su and O. B. Toon \\ Department of Atmospheric and Oceanic Sciences, Laboratory for Atmospheric and Space Physics, University of Colorado, \\ Boulder, Colorado, USA
}

Received: 23 October 2010 - Published in Atmos. Chem. Phys. Discuss.: 2 December 2010

Revised: 16 March 2011 - Accepted: 24 March 2011 - Published: 5 April 2011

\begin{abstract}
This study compares the properties of atmospheric dust from the Saharan deserts and the Asian deserts using data from CALIPSO and AERONET during 2006 and 2007 along with simulations using a coupled climatemicrophysical sectional model. Saharan deserts are largely south of $30^{\circ} \mathrm{N}$, while Asian ones are primarily north of $30^{\circ} \mathrm{N}$, hence they experience different meteorological regimes. Saharan dust lifting occurs all year long, primarily due to subtropical weather systems. However, Asian dust is lifted mostly in spring when mid-latitude frontal systems lead to high winds. Rainfall is more abundant over Asia during the dust lifting events, leading to greater local dust removal than over the Sahara. However, most dust removal is due to sedimentation. Despite the different meteorological regimes, the same dust lifting schemes work in models for Asian and Saharan dust. The magnitudes of dust lifted in Africa and Asia differ significantly over the year. In our model the yearly horizontal dust flux just downwind of the African dust source is about $1088 \mathrm{Tg}\left(10^{\circ} \mathrm{S}-40^{\circ} \mathrm{N}\right.$, $10^{\circ} \mathrm{W}$ ) and from the Asian dust source it is about $355 \mathrm{Tg}$ $\left(25^{\circ} \mathrm{N}-55^{\circ} \mathrm{N}, 105^{\circ} \mathrm{E}\right)$ in 2007 , which is comparable to previous studies. We find the difference in dust flux is mainly due to the larger area over which dust is lifted in Africa than Asia. However, Africa also has stronger winds in some seasons. Once lifted, the Saharan dust layers generally move toward the west and descend in altitude from about $7 \mathrm{~km}$ to the surface over several days in the cases studied. Asian dust often has multiple layers (two layers in the cases studied) during transport largely to the east. One layer stays well above boundary layer during transport and shows little descent, while the other, lower, layer descends with time. This observation contrasts with studies suggesting the descent of
\end{abstract}

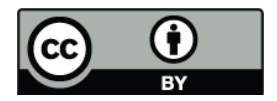

Correspondence to: $\mathrm{L}$. Su

(sul@colorado.edu)
Saharan dust is due to sedimentation of the particles, and suggests instead it is dominated by meteorology. We find the size distributions of Asian and African dust are similar when the dust is lifted, but the mode size can differ and secondary size modes can develop probably due to differences in vertical wind velocities during transport. The single scattering albedo of African and Asian dust does differ, due primarily to the imaginary parts of the refractive indexes being different, which in turn is likely due to different dust composition. This study is a step towards a global understanding of dust and its properties.

\section{Introduction}

Airborne mineral dust is one of the major components of atmospheric aerosols. Dust plays an important role in the atmospheric global circulation (Dunion and Velden, 2004; Wu, 2007), air pollution (Prospero, 1999; VanCuren, 2003), biogeochemical processes (Duce, 1991; Martin et al., 1994; Shinn et al., 2000), radiative budget (Sokolik and Toon, 1996; Kaufman et al., 2001), and human health (IPCC, 2007). Dust varies over short time scales and geologic time (Rea et al., 1985).

The Saharan desert is the largest and most continuous dust source in the world. Saharan dust can be transported across the tropical North Atlantic and into the Caribbean region as well as into Europe (Prospero and Carlson, 1972; Prospero, 1996; Colarco et al., 2002, 2003a, b; Toon, 2003; Liu, Z., 2008b et al., 2008; Generoso et al., 2008). Especially in summer large amounts of Saharan dust are transported across the Atlantic Ocean, which is dominated by the Azores High, and arrive in the Caribbean Sea (Doherty et al., 2008).

The Taklimakan and Gobi deserts are the major dust sources in Asia (Uno et al., 2005). Asian dust can be

Published by Copernicus Publications on behalf of the European Geosciences Union. 
transported over the North Pacific Ocean and reach Midway and North America (Duce et al., 1980; Shaw, 1980; Betzer et al., 1988; Clarke et al., 2001; Husar et al., 2001; Tratt et al., 2001; Huang et al., 2008; Eguchi et al., 2009; Su and Toon, 2009). Asian dust also can be transported over global scales (Clarke et al., 2001; Grousset et al., 2003; Uno et al., 2009).

In this paper, we refer to all of the major dust lifting regions in Africa and Asia as Saharan or Asian deserts. These dust lifting regions for Asia can be seen from the dust flux maps given in Su and Toon (2009).

Recently, special attention has been paid to Saharan dust in field campaigns such as the Puerto Rico Dust Experiment (PRIDE) (Reid et al., 2002, 2003; Maring et al., 2003; Colarco et al., 2003a, b), the Dust And Biomass EXperiment (DABEX) (Osborne et al., 2008), the SAharan Mineral dUst experiMent (SAMUM) (Heintzenberg, 2008; Knippertz et al., 2008; Muller et al., 2008), the African Monsoon Multidisciplinary Analysis (AMMA) (Rajot et al., 2008; Heese and Wiegner, 2008; Haywood et al., 2008), and the GERB Intercomparison of Longwave and Shortwave radiation (GERBILS) (Haywood et al., 2005; Marsham et al., 2008). Saharan dust has been studied through model simulations (Marticorena et al., 1997; Colarco et al., 2002, 2003a, b; Maring et al., 2003; Liu et al., 2008; Generoso et al., 2008), and satellite retrievals (D. Liu et al., 2008; Z. Liu et al., 2008b; Generoso et al., 2008; Cuesta et al., 2009).

Several field campaigns have been also conducted regarding Asian dust aerosols including the Aerosol Characterization Experiments (ACE-Asia) (Huebert et al., 2003; Seinfeld et al., 2004), the Indian Ocean Experiment (INDOEX) (Ramanathan et al., 2001, Rasch et al., 2001), the TRAnsport and Chemical Evolution over the Pacific experiment (TRACE-P) (Carmichael et al., 2003; Jacob et al., 2003), the Intercontinental Chemical Transport Experiment Phase B (INTEX-B) (Arellano et al., 2007; McKendry et al., 2008), and the PACific Dust EXperiment (PACDEX) (Stith et al., 2009). Asian dust also has been investigated through model simulations (Tegen and Fung, 1994; Schulz et al., 1998; Mahowald et al., 1999, 2006; Ginoux et al., 2001; Uno et al., 2002, 2004, 2008, 2009; Carmichael et al., 2003; Chin et al., 2003, 2004; Gong et al., 2003; Zender et al., 2003a; Shimizu et al., 2004; Shao and Dong, 2006; Huang et al., 2009; Su and Toon, 2009), and satellite retrievals (Huang et al., 2007, 2008; Liu et al., 2008; Uno et al., 2008).

Most studies have focused on either Saharan dust or Asian dust. Here we investigate the differences and similarities in dust lifting, dust removal processes, seasonal variations, transport mechanisms, and physical properties between Saharan dust and Asian dust using satellite data such as CALIPSO, ground-based data such as AERONET, and numerical models.

Numerous satellite observations have been made of Saharan and Asian dust. Here we focus on data from the CloudAerosol Lidar and Infrared Pathfinder Satellite Observation (CALIPSO). CALIPSO was launched in April 2006 (Liu et al., 2006; Winker et al., 2007). The Cloud - Aerosol Lidar with Orthogonal Polarization (CALIOP), on CALIPSO, is a two-wavelength (532 and $1064 \mathrm{~nm}$ ), polarization-sensitive (at $532 \mathrm{~nm}$ ) instrument. CALIOP provides substantial and unique information on vertical and geographical distributions of clouds and aerosols. CALIOP conducts nearly continuous observations of height-resolved attenuated backscatter over the globe (Sassen, 2000; Winker et al., 2003, 2010).

The Aerosol Robotic NETwork (AERONET) is a globally distributed remote sensing aerosol-monitoring network of ground-based sun photometers that measure sun and sky radiances in 16 spectral channels (340-1640 nm) (Holben et al., 1998). AERONET provides observations of aerosol optical depth (AOD), inversion products such as size distribution and single scattering albedo, and precipitable water. We use the cloud-screened and quality-assured AERONET Level 2.0 data in this study (Smirnov et al., 2000).

Numerical modeling of dust aerosols is essential for climate studies, and to better understand the behavior of the dust aerosols in the atmosphere. We use a coupled threedimensional climate-microphysical sectional model, which is capable of simulating the mineral dust aerosols ( $\mathrm{Su}$ and Toon, 2009) to explore the differences between atmospheric dust from the Saharan deserts and from the Asian deserts.

The various observations and models have led to a number of questions about Asian and African dust. It is clear from satellite observations that the dust optical depth is generally larger over the Atlantic, than over the Pacific. Is this difference due to more dust being lifted over Africa, to more dust being removed over the Pacific, to seasonality in dust lifting, or to other factors? Is the size distribution of dust downwind of African or Asian dust sources different, or the same so that it can be modeled using the same dust source functions? Are the dust optical properties different between Asian and African dust, and if so are the differences related to dust composition, or to particle size? Do the same mechanisms control dust transport in the two regions of the world? For instance, Saharan dust is observed to descend when crossing the Atlantic. Is this descent due to sedimentation, so Asian dust should also descend, or to air motions which may differ? Does the different meteorology of Africa and Asia lead to differences in the vertical distribution of the two types of dust? We seek to answer these questions here.

Section 2 of this paper describes our three-dimensional coupled model configuration and the dust emission scheme. Section 3 describes the CALIPSO and AERONET data. Section 4 evaluates the model results and provides comparisons with observations for seasonal and geographic variation in dust lifting and removal, for geographic differences in dust vertical distributions, for dust size distributions, and for dust optical properties. Section 5 presents a summary and conclusions. 


\section{Model description}

The three-dimensional coupled climate-aerosol microphysical model based on the NCAR Community Atmosphere Model (CAM3) (Collins et al., 2004) and the University of Colorado/NASA Community Aerosol and Radiation Model for Atmospheres (CARMA2.3) (Toon et al., 1988; Jensen et al., 1994; Ackerman et al., 1995) is a new numerical model that has been described in detail by $\mathrm{Su}$ and Toon (2009). The coupled model we are using for the Saharan and Asian dust simulations includes a three-dimensional climate model (CAM3) and an aerosol microphysical sectional model (CARMA2.3). CAM3 is driven by off-line meteorological fields from NCAR and the National Center for Environmental Prediction (NCEP) reanalysis package (Kistler et al., 2001). We treat CARMA2.3 as a binresolved column aerosol-microphysical sectional model that has the same domain as CAM3. We also choose the finitevolume (FV) dynamical core for the dynamical equations of CAM3 to conserve the mass for tracers as discussed by Lin and Rood (1996). The coupled CAM3/CARMA2.3 model includes dust sources, transport, removal processes, and optical properties of dust aerosols (Su and Toon, 2009).

We configured the coupled CAM3/CARMA2.3 model with a horizontal resolution of $2^{\circ} \times 2.5^{\circ}$ degrees, and 28 hybrid vertical model layers from the surface to about $40 \mathrm{~km}$. We used 16 dust size bins with central radius covering the range from 0.1 to $10 \mu \mathrm{m}$ to parameterize the modified Ginoux et al. (2001) dust source function as discussed in Su and Toon (2009). Briefly, the dust lifting is physically driven by the surface stress based on the saltation-sandblasting process (Gomes et al., 1990; Shao and Raupach, 1993; Shao and Lu, 2000; Su and Toon, 2009). We use the friction wind velocity in the dust source function based on the atmospheric stability and land surface conditions (e.g. surface roughness length). We also account for the recently detected desertification in Inner Mongolia in the dust erodibility source factor (Chin et al., 2003, 2004; P. Ginoux, personal communication, 2007; Su and Toon, 2009). The Weibull wind distribution that represents the subgrid-scale velocity distribution has been implemented in the dust-lifting scheme to better represent the dust lifting process by subgrid scale winds that are not represented well due to the coarse resolution of global models (Gillette and Passi, 1988; Su and Toon, 2009).

We use the same parameterization of removal processes (wet deposition and dry deposition) as described in Su and Toon (2009). Dust aerosols are scavenged both by rain and snow including below-cloud and in-cloud scavenging for each model layer in a manner that is size and composition independent (Barth et al., 2000; Rasch et al., 2001; $\mathrm{Su}$ and Toon, 2009). The dry deposition includes sedimentation near the surface (which dominates for coarse mode particles) and turbulent mix-out (which dominates for fine mode particles). The sedimentation fall velocities are calculated in CARMA2.3 by Stokes law at low Reynold's number
$(R e<1)$. Corrections are made at high Reynold's numbers $(R e>1)$ based on Prupacher and Klett (1996). We modified the dry deposition scheme following Marticorena and Bergametti (1995) and Ginoux et al. (2001) to account for both the bin-resolved dust particles and the effect of soil moisture on dust lifting (Su and Toon, 2009).

A systematic assessment of the model simulations has been done in Su and Toon (2009). We validated the simulations against observations from the ACE-Asia field campaign. We also used observational datasets including AERONET data at six study sites as well as the NIES lidar data to constrain the model simulations in $\mathrm{Su}$ and Toon (2009).

\section{The CALIPSO and AERONET data}

CALIPSO was launched in April 2006 (Liu et al., 2006; Winker et al., 2007). The Cloud - Aerosol Lidar with Orthogonal Polarization (CALIOP) instrument, on CALIPSO, is a two-wavelength (532 and $1064 \mathrm{~nm}$ ), polarizationsensitive (at $532 \mathrm{~nm}$ ) instrument. CALIOP provides substantial and unique information on vertical and geographical distributions of clouds and aerosols. CALIOP conducts nearly continuous observations of height-resolved attenuated backscatter over the globe (Sassen, 2000; Winker et al., 2003). We use CALIPSO profile level 1B data and the CALIPSO cloud layer level 2 data in this study.

The Aerosol Robotic NETwork (AERONET) is a globally distributed remote sensing aerosol-monitoring network of ground-based sun photometers that measure sun and sky radiances in 16 spectral channels $(340-1640 \mathrm{~nm})$ (Holben et al., 1998). AERONET provides observations of aerosol optical depth (AOD), as well as inversion products such as size distribution, single scattering albedo, and precipitable water. We use the cloud-screened and quality-assured AERONET Level 2.0 data in this study (Smirnov et al., 2000).

\section{Results}

\subsection{Comparison of dust abundance and fluxes over the Atlantic and Pacific, and seasonal variations}

Here we address the problem of why the optical depths of dust over the Pacific and Atlantic are so different. Figure 1 shows the daily-averaged and column-integrated spectral optical depth at $500 \mathrm{~nm}$ at Osaka in the Pacific in May 2007 (top) and at Capo Verde in the Atlantic in July 2007 (bottom) both from our model and from AERONET data. In general, the optical depth is higher over the Atlantic at Capo Verde than over Pacific at Osaka at similar downwind distances from the two dust sources even during the primary months of dust storm activity (such as May in Asia and July in the Sahara). The monthly-averaged optical depth is 0.382 and 0.339 over the Pacific at Osaka in May 2007 for AERONET 

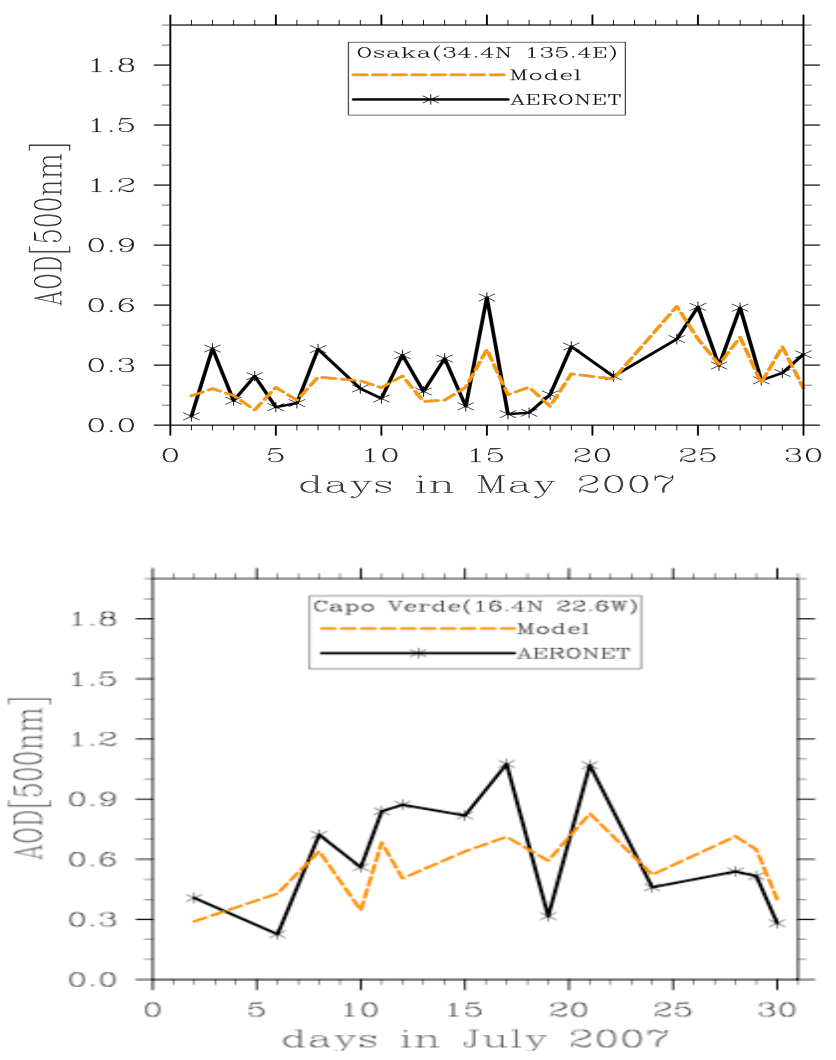

Fig. 1. The daily-averaged and column-integrated spectral optical depth (500 nm) at Osaka in May 2007 (top) and at Capo_Verde in July 2007 (bottom) both from our model and from AERONET data.

data and the model simulation, respectively. However, the monthly-averaged optical depth is 0.613 and 0.579 over the Atlantic at Capo Verde in July 2007 for AERONET data and model simulation, respectively.

The dust fluxes into the two ocean basins tell a similar story to the one told by the optical depths. Figure 2 shows the modeled dust fluxes for the Sahara in 2007 from $10^{\circ} \mathrm{S}-$ $40^{\circ} \mathrm{N}$ latitude across four different longitude planes at $10^{\circ} \mathrm{W}$, $55^{\circ} \mathrm{W}, 100^{\circ} \mathrm{W}$, and $145^{\circ} \mathrm{W}$. Figure 3 shows the map used in this study for Saharan dust. The dashed lines denote the four longitude planes $\left(10^{\circ} \mathrm{W}, 55^{\circ} \mathrm{W}, 100^{\circ} \mathrm{W}\right.$, and $\left.145^{\circ} \mathrm{W}\right)$ and the latitude boundaries $\left(10^{\circ} \mathrm{S}\right.$ to $\left.40^{\circ} \mathrm{N}\right)$ at which dust fluxes were computed. We choose the latitude range between $10^{\circ} \mathrm{S}$ to $40^{\circ} \mathrm{N}$ based on previous studies using the GEOSChem model and CALIPSO analysis (Generoso et al., 2008; Liu et al., 2008b) suggesting that most Saharan dust plumes occurred and were transported downwind within this area. These longitudes span the distance from the Saharan dust source regions, across the Atlantic, over the Caribbean and into the Pacific. The net dust flux (orange dashed line in Fig. 2) crossing the $10^{\circ} \mathrm{W}$ plane $\left(10^{\circ} \mathrm{S}-40^{\circ} \mathrm{N}\right)$ at the western edge of the Saharan Desert is about $90 \mathrm{Tg}$ for each month and is about $110 \mathrm{Tg}$ per summer month when the flux is greatest. The annual net flux is about $1088 \mathrm{Tg}$ across the $10^{\circ} \mathrm{W}$ plane

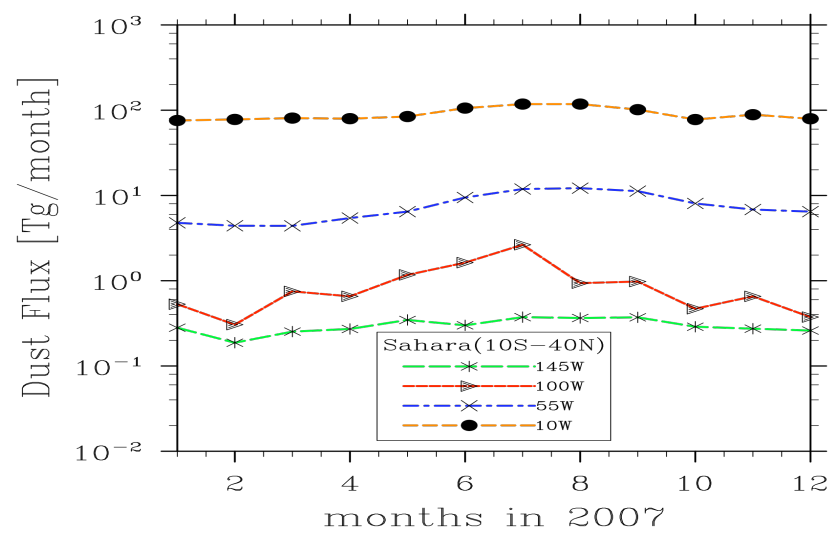

Fig. 2. Modeled monthly dust flux between $10^{\circ} \mathrm{S}-40^{\circ} \mathrm{N}$, across different longitude planes $\left(10^{\circ} \mathrm{W}, 55^{\circ} \mathrm{W}, 100^{\circ} \mathrm{W}\right.$, and $\left.145^{\circ} \mathrm{W}\right)$ for Saharan dust in 2007.

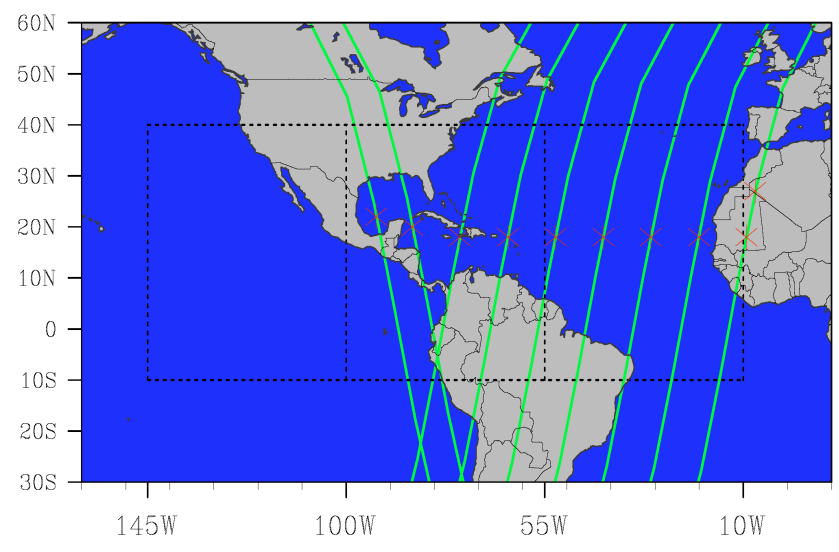

Fig. 3. Map used in this study for Saharan dust. The dashed lines denote the four longitude planes $\left(10^{\circ} \mathrm{W}, 55^{\circ} \mathrm{W}, 100^{\circ} \mathrm{W}\right.$, and $\left.145^{\circ} \mathrm{W}\right)$ and the latitude boundary $\left(10^{\circ} \mathrm{S}\right.$ to $\left.40^{\circ} \mathrm{N}\right)$. The CALIPSO tracks are shown as lines along the asterisks.

in 2007 (orange dashed line in Fig. 2). The flux across the $10^{\circ} \mathrm{W}$ plane is about $70 \%$ of the total amount of Saharan dust $(1547 \mathrm{Tg})$ lifted in the model for the year 2007. About 6\% of the dust $(93 \mathrm{Tg}$ ) goes north toward Europe in the model. Another $3 \%$ of the dust is lifted to the west of the $10^{\circ} \mathrm{W}$ plane. The remainder of the dust (about $21 \%$ of that lifted) is removed locally over the Sahara before it can reach the $10^{\circ} \mathrm{W}$ plane.

The Saharan Desert is located in the tropics and subtropics, and usually experiences deep convection throughout the year. Strong winds embedded in the tropical trades (northeasterly flow) continually lift dust from the surface of Saharan Deserts. The dust outbreaks are contained in a deep mixed layer. The deep mixed layer usually extends to 5-6 km or higher in altitude over the Saharan Deserts due to the strong solar heating (Prospero et al., 1972; Prospero and Carlson, 1981; Karyampudi et al., 1999; Colarco et al., 2003b). This hot and dry air mass is advected west of Africa 
and referred to as the Saharan Air Layer (SAL). Dust lifting over African can be triggered and modulated by synoptic systems, such as African easterly waves in the Atlantic region (Prospero and Carson, 1972; Westphal et al., 1987; Jones et al., 2003). The dust outbreaks usually occur in the ridge of passing easterly waves with a period of 5-7 days (Prospero and Carson, 1972). The African easterly waves are identified through filtered (2.5-10 days) relative vorticity at $700 \mathrm{hPa}$ over the tropical Atlantic Ocean. About 20\% of the dust entrainment into the atmosphere is related to easterly wave activity, and approximately $10 \%-20 \%$ of the seasonal variation of Saharan Desert dust transported across the North Atlantic Ocean is regulated by easterly waves (Jones et al., 2003).

Figures 2 and 4 show that about $90 \%$ of the dust is removed by the time it reaches $55^{\circ} \mathrm{W}$. During most months of the year only about $1 \%$ of the dust reaches as far as $100^{\circ} \mathrm{W}$, the longitude of Mexico. However, in the summer of 2007 our model indicates a relatively larger dust flux (around $1.9 \mathrm{Tg}$ month $^{-1}, 3.6 \%$ of total dust flux) reached the west coast of the Caribbean Sea (the $100^{\circ} \mathrm{W}$ plane red curve in Fig. 2). These dust fluxes are qualitatively consistent with previous studies. Colarco et al. (2003b) and Doherty et al. (2008) indicate each summer large amounts of Saharan dust are transported across the Atlantic Ocean and arrive in Caribbean Sea. The Saharan dust transport into the Caribbean is controlled primarily by a semi- permanent high, the Azores High (also called North Atlantic High), which usually extends westward toward Bermuda. This anticyclone becomes stronger and moves north in summer, and it moves south and becomes weaker in winter. The longitudinal displacement of the Azores High is highly related to the Saharan dust transport into the Caribbean.

Figure 2 also shows that the far-most plane over the Pacific at $145^{\circ} \mathrm{W}$ (the asterisk marked dash-line) indicates a significant loss of dust between $100^{\circ} \mathrm{W}$ and $145^{\circ} \mathrm{W}$ in the months of June, July and August. The amount of loss in this longitude region is related to the position of the Inter-tropical Convergence Zone (ITCZ). During summer the ITCZ moves into latitudes near $10^{\circ} \mathrm{N}$, and there is significant convection over Central America due to the frontal zone of the ITCZ bringing the warm, moist air from the Gulf of Guinea into the hot, dry Saharan air to the north. This convection is quite efficient at removing the dust (Pfister et al, 2010). However, during other parts of the year there is less convection over Central America and our model suggests that dust is more likely to reach the Pacific.

Figure 4 presents the modeled monthly dust flux between $10^{\circ} \mathrm{S}$ to $40^{\circ} \mathrm{N}$ for 2007 at various longitudes as a fraction of the flux at $10^{\circ} \mathrm{W}$. The $55^{\circ} \mathrm{W}$ to $10^{\circ} \mathrm{W}$ ratio shows a monthly variation that may be related to the position of the Azores High as we discussed earlier. Generoso et al. (2008) estimated $151 \mathrm{Tg}$ of dust was deposited in 2006 in the area bounded by $5^{\circ} \mathrm{N}-27^{\circ} \mathrm{N}$ and $17^{\circ} \mathrm{W}-100^{\circ} \mathrm{W}$. We similarly find that total annual dust deposition in the tropical Atlantic

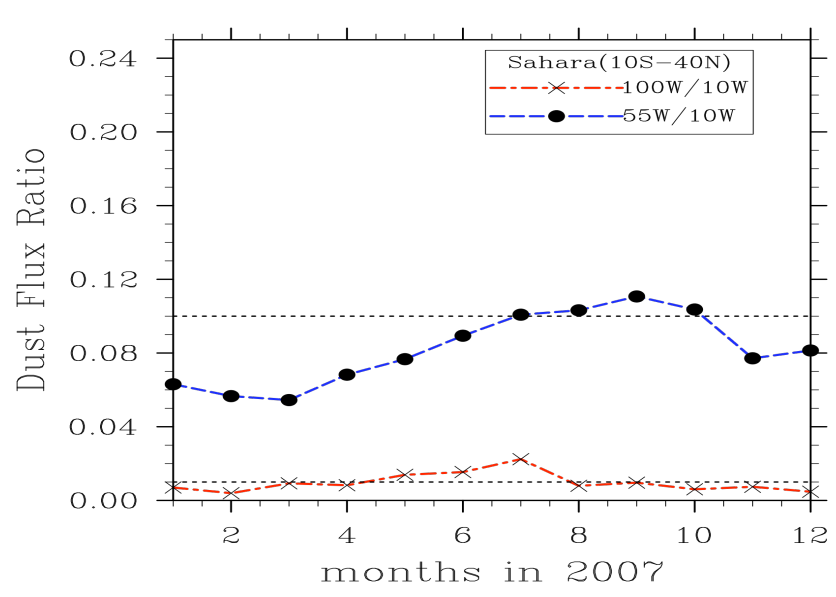

Fig. 4. Modeled monthly mean dust flux between $10^{\circ} \mathrm{S}$ to $40^{\circ} \mathrm{N}$. The asterisk-marked line denotes the ratio of the flux as $100^{\circ} \mathrm{W}$ to that at $10^{\circ} \mathrm{W}$, and the blue dashed-line denotes the ratio of the flux at $55^{\circ} \mathrm{W}$ to that at $10^{\circ} \mathrm{W}$ for Saharan dust in 2007. The dashed lines mark 0.1 and 0.01 .

in the area bounded by $5^{\circ} \mathrm{N}-30^{\circ} \mathrm{N}$ and $17^{\circ} \mathrm{W}-100^{\circ} \mathrm{W}$ is about $163 \mathrm{Tg}$ in 2007.

Figure 5 shows the modeled annual dust wet deposition between $10^{\circ} \mathrm{S}$ to $40^{\circ} \mathrm{N}$ for $10^{\circ} \mathrm{W}-55^{\circ} \mathrm{W}, 55^{\circ} \mathrm{W}-100^{\circ} \mathrm{W}$, and $100^{\circ} \mathrm{W}-145^{\circ} \mathrm{W}$ for Saharan dust in 2007 . The annual total of the dust wet deposition over $10^{\circ} \mathrm{S}$ to $40^{\circ} \mathrm{N}$ and $10^{\circ} \mathrm{W}$ to $145^{\circ} \mathrm{W}$ is $122 \mathrm{Tg}$ based on the model simulations. Over the year there are about total $112 \mathrm{Tg}$ (10\% of total annual dust flux of $1088 \mathrm{Tg}$ crossing the $10^{\circ} \mathrm{W}$ plane), $9 \mathrm{Tg}(10 \%$ of total annul dust flux of $92 \mathrm{Tg}$ crossing the $55^{\circ} \mathrm{W}$ plane), and $0.8 \mathrm{Tg}$ ( $8 \%$ of total annual dust flux of $11.09 \mathrm{Tg}$ crossing the $100^{\circ} \mathrm{W}$ plane) of dust removed during transport between $10^{\circ} \mathrm{W}$ and $55^{\circ} \mathrm{W}, 55^{\circ} \mathrm{W}$ and $100^{\circ} \mathrm{W}, 100^{\circ} \mathrm{W}$ and $145^{\circ} \mathrm{W}$, respectively, by wet deposition. Therefore the results of our model simulation indicate that $10 \%$ of total dust crossing $10^{\circ} \mathrm{W}$ is deposited before it reaches the $145^{\circ} \mathrm{W}$ plane in 2007 by wet removal, of which about $60 \%$ of the wet deposition occurs in summer. There is less wet deposition in spring and autumn. Our study suggests that the wet removal process is a minor contributor to the total dust loss over the Atlantic (see Table 1.).

Figure 6 shows the modeled annual dust fluxes (between $\left.25^{\circ} \mathrm{N}-55^{\circ} \mathrm{N}\right)$ across different longitude planes $\left(105^{\circ} \mathrm{E}\right.$, $150^{\circ} \mathrm{E}, 195^{\circ} \mathrm{E}$, and $240^{\circ} \mathrm{E}$ ) for Asian dust in 2007. Figure 7 shows the map used in this study for Asian dust. The dashed lines denote the four longitude planes $\left(105^{\circ} \mathrm{E}\right.$, $150^{\circ} \mathrm{E}, 195^{\circ} \mathrm{E}$, and $240^{\circ} \mathrm{E}$ ) and the latitude boundaries $\left(25^{\circ} \mathrm{N}\right.$ to $\left.55^{\circ} \mathrm{N}\right)$. We chose the latitude range between $25^{\circ} \mathrm{N}$ to $55^{\circ} \mathrm{N}$ based on previous modeling and observational studies showing that most Asian dust plumes occurred and were transported downwind within this area (Eguchi et al., 2003, 2009; Huang et al., 2008). The total dust flux (orange dashed line in Fig. 6) across the $105^{\circ} \mathrm{E}$ plane, which crosses central Mongolia in the Asian deserts, is $355 \mathrm{Tg}$ in 2007 . Only about 


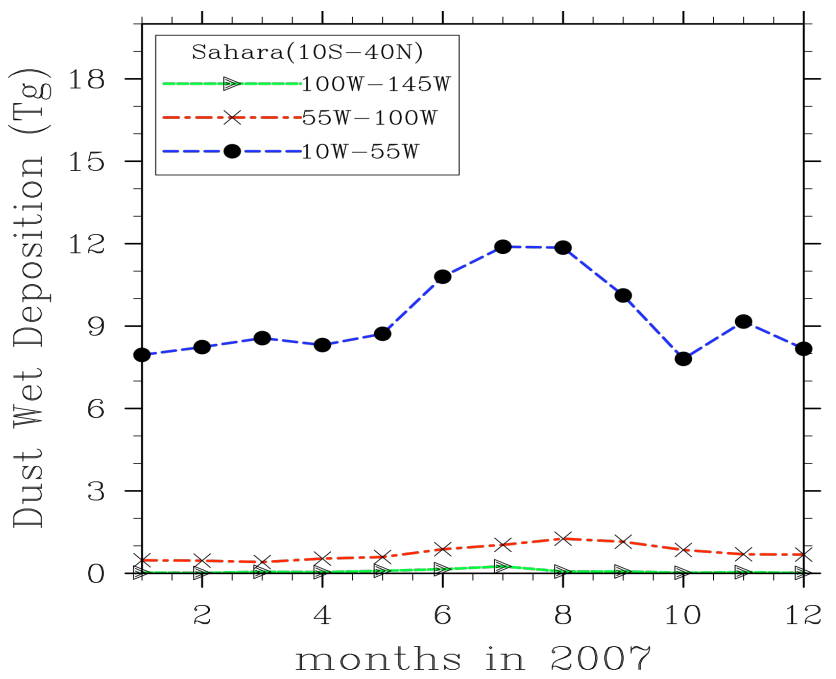

Fig. 5. Modeled monthly dust wet deposition between $10^{\circ} \mathrm{S}$ to $40^{\circ} \mathrm{N}$ for longitudes between $10^{\circ} \mathrm{W}$ to $55^{\circ} \mathrm{W}, 55^{\circ} \mathrm{W}-100^{\circ} \mathrm{W}$, and $100^{\circ} \mathrm{W}-145^{\circ} \mathrm{W}$ for Saharan dust in 2007.

Table 1. The factors that contribute to the magnitudes of the total dust fluxes both for Asian and Saharan dust simulated from the coupled CAM3.0/CARMA2.3 model in 2007. The \% in the first two lines (wet and dry deposition) refers to the fraction of the dust removed before traveling 45 degrees of longitude from the sources.

\begin{tabular}{lll}
\hline $\begin{array}{l}\text { Impact factors } \\
\text { (annual average) }\end{array}$ & $\begin{array}{l}\text { Asian dust } \\
\text { (total dust flux } \\
\text { across source } \\
\text { plane is 355 Tg } \\
\text { in 2007) }\end{array}$ & $\begin{array}{l}\text { Saharan dust } \\
\text { (total dust flux } \\
\text { across source } \\
\text { plane is 1088 Tg } \\
\text { in 2007) }\end{array}$ \\
\hline Wet deposition & $15 \%$ & $10 \%$ \\
Dry deposition & $75 \%$ & $80 \%$ \\
Soil Erodibility Factor & 0.077 & 0.081 \\
Area of sources & $2.07 \times 10^{6} \mathrm{~km}^{2}$ & $8.95 \times 10^{6} \mathrm{~km}^{2}$ \\
Area lifting occurs & $1.33 \times 10^{6} \mathrm{~km}^{2}$ & $4.17 \times 10^{6} \mathrm{~km}^{2}$ \\
Power averaged wind & $4.2 \mathrm{~m} \mathrm{~s}^{-1}$ & $5.1 \mathrm{~m} \mathrm{~s}^{-1}$ \\
Soil moisture & $0.1 \mathrm{~mm}^{3} \mathrm{~mm}^{-3}$ & $0.03 \mathrm{~mm}^{3} \mathrm{~mm}^{-3}$ \\
Snow (annual total) & $778 \mathrm{~mm}^{-3}$ & 0 \\
\hline
\end{tabular}

$4 \%$ of the total dust lifted over Asia comes from the east of $105^{\circ} \mathrm{E}$. Figure 2 showed an annual dust flux across $10^{\circ} \mathrm{W}$ from the Sahara of about $1088 \mathrm{Tg}$ in 2007. Therefore, about 3 times as much dust was transported downwind of the Sahara desert in 2007, as downwind of the Asian deserts. Unlike the case for the Sahara, there is a strong seasonal variation in Asian dust fluxes. We find that $62 \%$ of the $355 \mathrm{Tg}$ lifted is generated in the months March-June. Eguchi et al. (2003) reported that the dust transported through the longitudinal cross-plane at $90^{\circ} \mathrm{E}$ is approximately $34.1 \mathrm{Tg}$ for a period of 5-15 May 2007 based on a 3-D aerosol model. Our model estimates about $36.4 \mathrm{Tg}$ within the same latitude region between $25^{\circ} \mathrm{N}-55^{\circ} \mathrm{N}$.

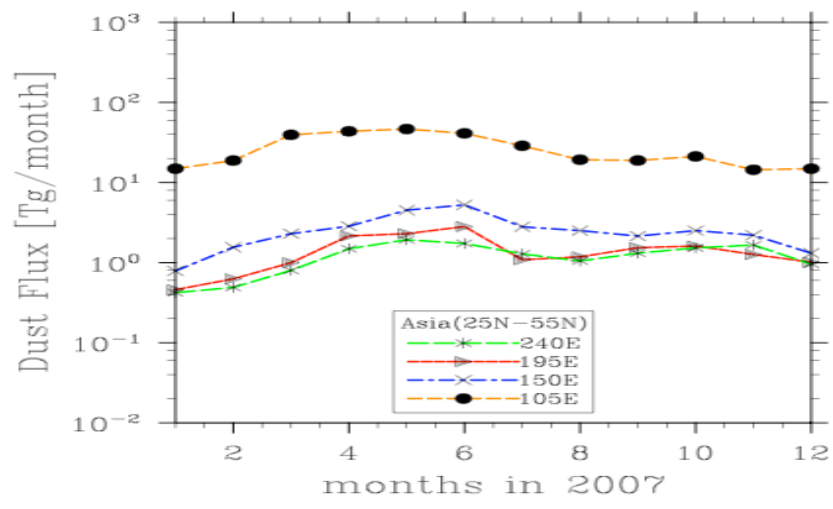

Fig. 6. Modeled monthly dust fluxes $\left(25^{\circ} \mathrm{N}-55^{\circ} \mathrm{N}\right)$ across different longitude planes $\left(105^{\circ} \mathrm{E}, 150^{\circ} \mathrm{E}, 195^{\circ} \mathrm{E}\right.$, and $\left.240^{\circ} \mathrm{E}\right)$ for Asian dust in 2007.

The seasonal variation of dust outbreaks over Asia is associated with variation in the wind speed (Shao and Dong, 2006), the surface vegetation (Lee and Sohn, 2009), and the soil moisture and snow cover (Laurent et al., 2006). Strong winds occur most frequently in spring in Asia due to the activity of mid-latitude frontal systems. The mid-latitude cyclones associated with intense cold fronts from Mongolia to northeastern China not only generate dust storms, but also lift Asian dust into the westerly jet in the free atmosphere. There is no equivalent of the SAL over Asia, though some of the dust is transported in a relatively shallow boundary layer. Deep dry convection is a major feature of Saharan Deserts (Cuesta et al., 2009). The mixed boundary layer depth and the tropopause altitude above the low-latitude tropical surface of Africa are higher than at mid-latitudes in Asia. Thus the springtime weather in Asia produces intense dust storm events in which dust is transported along the direction of the westerly winds. However, this transport is not associated with a deep convective boundary layer, as it is for Saharan dust.

The dust emission over the Asian dust source regions is substantially suppressed after spring not only due to the weaker Mongolian cyclonic activity but also because of the increasing vegetation (Lee and Sohn, 2009). Laurent et al. (2006) indicates that the soil moisture and snow cover in the northern deserts of China decreases the dust emission by $94 \%$ and $84 \%$, respectively, in winter but the dust emissions of Taklimakan desert are not noticeably influenced by the soil moisture and snow cover due to low precipitation and snowfall.

Figure 8 presents the monthly dust flux between $25^{\circ} \mathrm{N}$ to $55^{\circ} \mathrm{N}$ latitude across $240^{\circ} \mathrm{E}$ and $150^{\circ} \mathrm{E}$ longitudes as a fraction of the flux across $105^{\circ} \mathrm{E}$. Figure 8 shows that only about $10 \%$ of the dust lifted reaches the longitude of Japan $\left(150^{\circ} \mathrm{E}\right)$ and only $5 \%$ reaches the West coast of the US $\left(240^{\circ} \mathrm{E}\right)$. This large mass loss suggests that the removal processes (including wet and dry deposition) play an essential role during the 


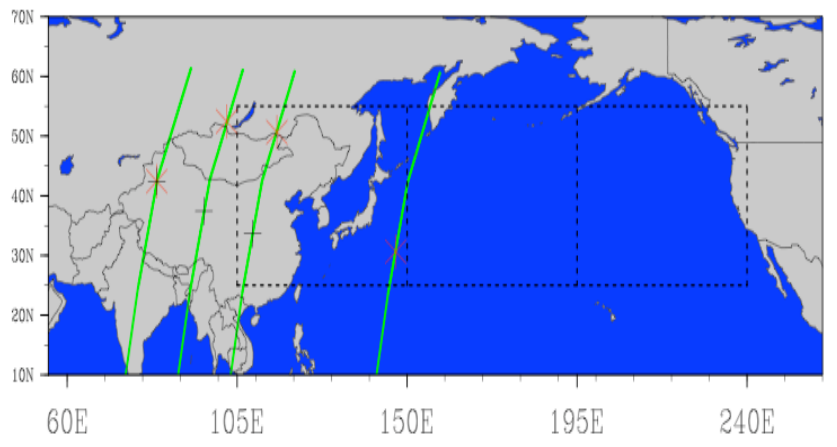

Fig. 7. Map used in this study for Asian dust. The dashed lines denote the four longitude planes $\left(105^{\circ} \mathrm{E}, 150^{\circ} \mathrm{E}, 195^{\circ} \mathrm{E}\right.$, and $\left.240^{\circ} \mathrm{E}\right)$ and the latitude boundary $\left(25^{\circ} \mathrm{N}\right.$ to $\left.55^{\circ} \mathrm{N}\right)$. The CALIPSO tracks are shown as lines along the asterisks and cross marks.

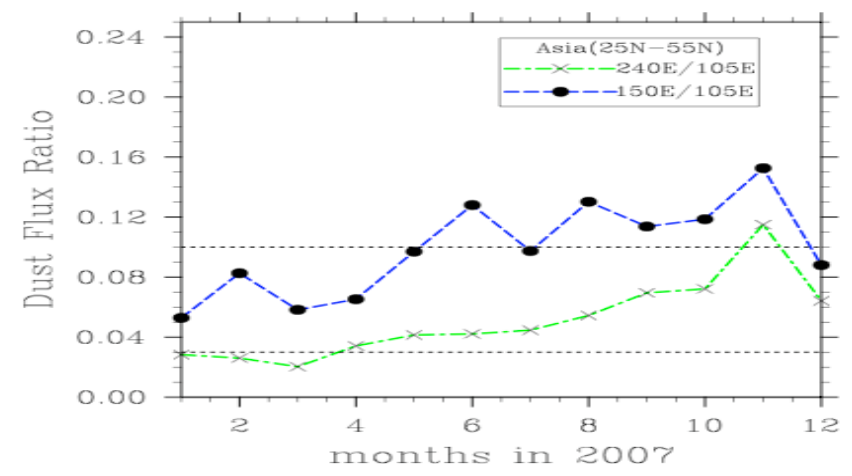

Fig. 8. Modeled ratios of monthly dust flux between $25^{\circ} \mathrm{N}$ to $55^{\circ} \mathrm{N}$ for Asian dust in 2007. The horizontal dashed lines are the 0.1 and 0.03 lines.

Asian dust transport to $150^{\circ} \mathrm{E}$. Like Sahara dust there is a low layer of Asian dust that is rapidly removed by deposition. However, the relatively small dust particles lifted from the dust source that are entrained into air at high altitude (up to $10 \mathrm{~km}$ ) can be transported via upper tropospheric westerly jets over long distances as has been pointed out from observations by Stith et al. (2009). Once dust passes Japan, removal is less important. Eguchi et al. (2009) reported that about $30 \%$ of dust crossing $140^{\circ} \mathrm{E}$ is transported eastward and arrives in the North America based on the CALIPSO and SPRINTARS model analysis, which is consistent with our model simulations of $40 \%$ of Asian dust crossing $150^{\circ} \mathrm{E}$ reaching the west coast of America.

The dust flux ratios in Fig. 8 are lowest in the months from December to May. This seasonal variability means there is preferential dust removal during the same period when dust is lifted over Asian deserts. This overlap occurs because the low pressure centers over the Asian deserts are not only responsible for the strong winds needed for the dust lifting, but also act as sources of rain needed for dust removal. This is a different phenomenon than for Sahara dust.

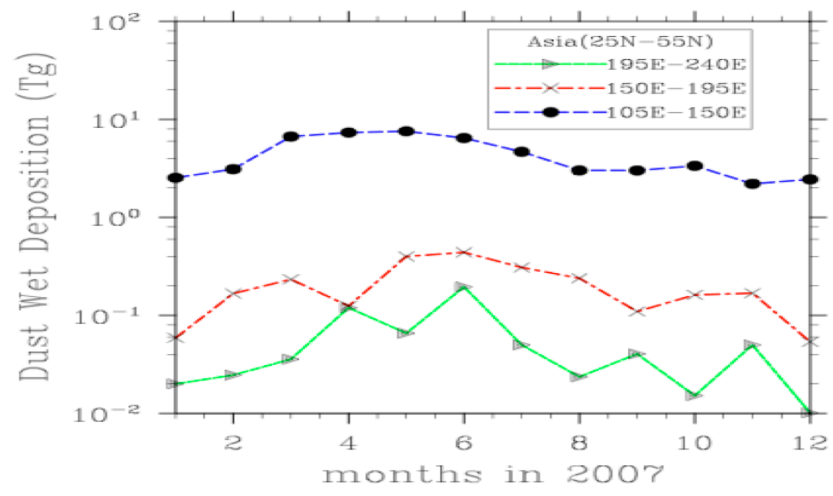

Fig. 9. Modeled monthly dust wet deposition between $25^{\circ} \mathrm{N}$ to $55^{\circ} \mathrm{N}$ for regions between $105^{\circ} \mathrm{E}$ to $150^{\circ} \mathrm{E}, 150^{\circ} \mathrm{E}$ to $195^{\circ} \mathrm{E}$, and $195^{\circ} \mathrm{E}$ to $240^{\circ} \mathrm{E}$ for Asian dust in 2007.

Figure 9 shows the modeled annual dust wet deposition between $25^{\circ} \mathrm{N}$ to $55^{\circ} \mathrm{N}$ for $105^{\circ} \mathrm{E}$ to $150^{\circ} \mathrm{E}, 150^{\circ} \mathrm{E}$ to $195^{\circ} \mathrm{E}$, and $195^{\circ} \mathrm{E}$ to $240^{\circ} \mathrm{E}$ for Asian dust in 2007 . The dust flux is correlated with the wet removal. In part this is because the same systems that lift the dust, bring rain. About $52 \mathrm{Tg}(15 \%$ of dust crossing the $105^{\circ} \mathrm{E}$ plane) of dust is removed during transport from $105^{\circ} \mathrm{E}$ to $150^{\circ} \mathrm{E}$ by wet deposition on an annual average. The results of our model simulation indicate that more dust is wet deposited during spring and summer, than in autumn and winter. This study also suggests that wet removal process plays a larger role in dust removal for Asian dust ( $15 \%$ of dust crossing the $105^{\circ} \mathrm{E}$ plane) than Saharan dust ( $10 \%$ of dust crossing the $10^{\circ} \mathrm{W}$ plane). This larger loss is due to the abundant rainfall over Asia (especially in spring and summer) leading to greater local dust removal than over the Sahara.

The dust mass flux from the Sahara in 2007 is about 3 times greater than that from Asia across a plane that is 45 degrees longitude from the source. Table 1 shows the factors that contribute to the differences of the total dust fluxes between Asian dust and Saharan dust as simulated from the coupled CAM3.0/CARMA2.3 model in year 2007. We can see the wet and dry deposition processes have similar magnitudes for Asian and Saharan dust. Although most of the dust is removed in transport over these distances, deposition is not the major mechanism causing the differences in the total dust fluxes between the two dust sources. The soil erodibility factor (the fraction of the grid cell for which dust lifting occurs if the threshold wind velocity is exceeded) is not a function of time in the model. There are the similar values of the area averaged soil erodibility factor $(0.078$ for Asian deserts and 0.081 for Saharan deserts). The total areas of the dust sources are $2.07 \times 10^{6} \mathrm{~km}^{2}$ and $8.95 \times 10^{6} \mathrm{~km}^{2}$ for Asian deserts and Saharan deserts, respectively. However, the annual averaged areas over which dust lifting occurs (when wind exceeds the threshold velocity, which is related to the particle size distribution and soil moisture) are 
$1.33 \times 10^{6} \mathrm{~km}^{2}$ and $4.17 \times 10^{6} \mathrm{~km}^{2}$ for Asian deserts and Saharan deserts, respectively, based on the model simulations. The areas over which dust lifting occurs in various seasons in Saharan deserts are $3.97 \times 10^{6} \mathrm{~km}^{2}$ (spring), $4.53 \times 10^{6} \mathrm{~km}^{2}$ (summer), $4.25 \times 10^{6} \mathrm{~km}^{2}$ (fall), and $3.94 \times 10^{6} \mathrm{~km}^{2}$ (winter). The areas over the Asian deserts are $1.67 \times 10^{6} \mathrm{~km}^{2}$ (spring), $1.15 \times 10^{6} \mathrm{~km}^{2}$ (summer), $1.20 \times 10^{6} \mathrm{~km}^{2}$ (fall), and $1.31 \times 10^{6} \mathrm{~km}^{2}$ (winter). Therefore the different areas over which dust is lifted contributes about a factor of 3 to the difference in total dust lifting between the two sources in 2007. A factor of three is also about the difference in the spring and summer lifting between the Sahara and Asia, so that the area over which dust is lifted dominates the difference between the amounts of dust lifted. We also calculated the seasonal mean power-averaged wind over the dust lifting areas. The amount of dust lifted in the source function is directly proportional to the power in the wind. The values of the power-averaged winds are $4.9 \mathrm{~m} \mathrm{~s}^{-1}$ (spring), $5.5 \mathrm{~m} \mathrm{~s}^{-1}$ (summer), $5.3 \mathrm{~m} \mathrm{~s}^{-1}$ (fall), and $4.7 \mathrm{~m} \mathrm{~s}^{-1}$ (winter) for Saharan deserts. And the values of the power-averaged winds are $4.9 \mathrm{~m} \mathrm{~s}^{-1}$ (spring), $3.6 \mathrm{~m} \mathrm{~s}^{-1}$ (summer), $4.0 \mathrm{~m} \mathrm{~s}^{-1}$ (fall), and $4.3 \mathrm{~m} \mathrm{~s}^{-1}$ (winter) for Asian deserts. So the annualaveraged and power averaged winds for Asian deserts and Saharan deserts are $4.2 \mathrm{~m} \mathrm{~s}^{-1}$ and $5.1 \mathrm{~m} \mathrm{~s}^{-1}$, respectively. The wind speeds are the same between the Sahara and Asia in the spring, so when Asia has most of its dust events it is the area of the source that dominates the difference between Asian and African dust fluxes. However in other times of the year low winds speeds cause Asia to be a less important dust source. Over the year, wind speed contributes about a factor of 1.7 (the lifting depends on the third power of the wind) to the differences of the total dust fluxes between the African and Asian sources. Soil moisture and snow can be seen as restricting the area of the dust sources, or the magnitude of the dust lifting. The soil moisture (the volumetric soil water in the model) is different between the two sources with an annual mean value of $0.1 \mathrm{~mm}^{3} \mathrm{~mm}^{-3}$ for Asian deserts and $0.03 \mathrm{~mm}^{3} \mathrm{~mm}^{-3}$ for Saharan deserts (Table 1). The dust flux is not linearly proportional to the soil moisture. Soil moisture contributes about a factor of $10 \%$ to the total dust flux differences between the two sources. Other factors that affect the dust flux differences between the two sources can be snow and vegetation (the annual total snow is $778 \mathrm{~mm}$ over Asian deserts in 2007 and it is around zero for Saharan deserts in 2007 in the model). Snow and vegetation limit the area of dust lifting, not the magnitudes of dust lifting in our model.

\subsection{Dust vertical distribution}

We would like to know if Asian and African dust has the same vertical distribution, and to understand how the vertical distribution of dust impacts the downwind transport and properties of dust. As we noted in the previous section the removal over 45 degrees of longitude is similar for Africa and Asia. However, because these deserts are at different lat- itudes, the times to go these distances are shorter by about $20 \%$ for the Asian dust, assuming the wind speeds are similar. However, the mean wind speed at $30^{\circ} \mathrm{N}-50^{\circ} \mathrm{N}$ latitude is higher than at $10^{\circ} \mathrm{N}-30^{\circ} \mathrm{N}$ latitude, so in fact the Asian dust is traveling faster than the Saharan dust and so has even less time to be removed. In net the Asian dust has about 25\% less time to be removed than the African dust considering both distance and wind speed. We compare the vertical distribution of Saharan dust with that of Asian dust and explore how each evolves downwind of their respective source. We use data from the CALIOP instrument on CALIPSO for this comparison.

We investigated a case study of dust transport for Saharan dust and one for Asian dust. Over the tropical and subtropical regions the cloud coverage is very high, which makes it hard to acquire enough cloud-free profiles to create case studies. Due to the availability of CALIPSO measurements, we take 17 August to 28 August of 2006 as an example of Saharan dust, and 7 May to 10 May of 2007 as an example of Asian dust.

CALIPSO profile level 1B data contains measurements of Total Attenuated Backscatter at $532 \mathrm{~nm}$ (TAB_532) and of Perpendicular Attenuated Backscatter at $532 \mathrm{~nm}$ (PAB_532). Following Fernald (1984), Fernald et al. (1972), Young et al. (2008), Liu et al. (2008b), and Cuesta et al. (2009), the dust vertical extinction $\left(\mathrm{km}^{-1}\right)$ at $532 \mathrm{~nm}$ can be calculated (here we assume the aerosol layer is homogeneous along the laser beam) by

$\alpha_{532}=\frac{\beta_{532 \mathrm{t}} \times S_{532}}{\exp \left(-2 \times \alpha_{532} \times \Delta z\right)}$

Where $\beta_{532 \mathrm{t}}$ is the total attenuated backscatter at $532 \mathrm{~nm}$ $\left(\mathrm{km}^{-1} \mathrm{sr}^{-1}\right), \alpha_{532}$ is the vertical extinction $\left(\mathrm{km}^{-1}\right), S_{532}$ is the lidar ratio (44 for this study based on Liu et al. (2006)), and $\Delta z$ is the detected layer height. We also screen out the cloud from CALIPSO profile level $1 \mathrm{~B}$ data based on the CALIPSO cloud layer level 2 data based on Liu et al. (2008b). Nighttime CALIPSO measurements primarily are used in this study because they have less noise. However we use the daytime data for 25 and 28 August because the nighttime data are not available. We expect additional solar background noise in measurements on these two days.

Figure 3 shows the map of CALIPSO tracks for Saharan dust used in this study (17 August to 28 August of 2006). The asterisks indicate the dust transport path for Saharan Deserts from 17 August (most easterly asterisk) to $28 \mathrm{Au}-$ gust (most westerly asterisk) of 2006. It should be noted that there are two dust plumes on 17 August of 2006 (as two asterisks denoted), which merged together before it begins its long-range transport across the Atlantic on $18 \mathrm{Au}-$ gust of 2006. We averaged these two profiles on $17 \mathrm{Au}-$ gust. We used the Hybrid Single-Particle Lagrangian Integrated Trajectory (HYSPLIT) model (Draxler and Rolph, 2003) (http://www.arl.noaa.gov) to trace the downwind evolution of Saharan and Asian dust. The HYSPLIT model 


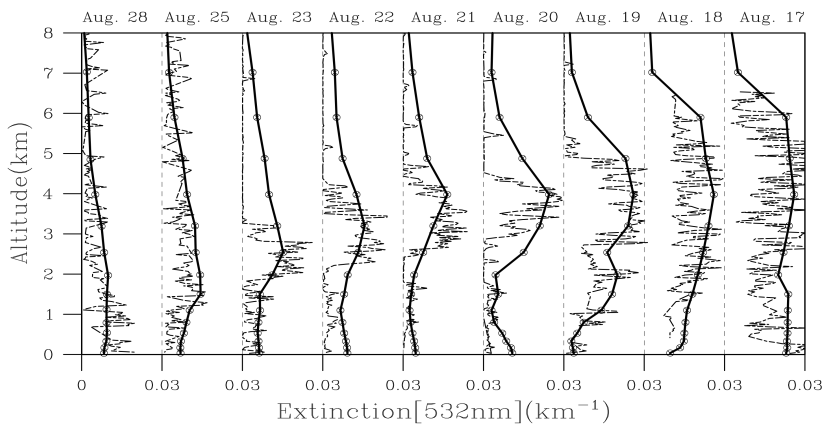

Fig. 10. Comparison of vertical distribution of Saharan dust between model simulations and CALIPSO observations in August of 2006.

can be configured to compute air parcel trajectories for complex dispersion and deposition simulations based on the wind fields from the National Center for Environmental Prediction (NCEP) analyses. We averaged the CALIPSO data every 120-laser shots over about $40 \mathrm{~km}$ along the track around the regions marked by asterisks. Figure 10 presents the results of the comparison of the vertical distribution (extinction at $532 \mathrm{~nm}$ ) of Saharan dust between the model (solid marked lines) and CALIPSO data by Eq. (1) (dashed lines) from 17 August to 28 August of 2006. The simulated dust vertical distribution of Sahara dust is generally consistent with CALIPSO (lidar) retrievals. However, on some days, such as from 19 August to 23 August the model does not capture the sharp layer top that is observed by CALIPSO. Probably the model lacks enough vertical resolution to fully resolve the layer top. However, it is also possible that the upper parts of the layer have been advected horizontally away from the lower parts and the model has not properly captured that transport. The Sahara dust layers descend over time with the top altitude starting at about $7 \mathrm{~km}$ on 17 August and reaching the marine boundary layer on 28 August. The typical magnitude of the vertical extinction (vertical average through the dust layer) decreases from $0.023 \mathrm{~km}^{-1}$ (averaged from the CALIPSO data) and $0.027 \mathrm{~km}^{-1}$ (averaged from the model) on 17 August to $0.01 \mathrm{~km}^{-1}$ (averaged from the CALIPSO data) and $0.007 \mathrm{~km}^{-1}$ (averaged from the model) on $28 \mathrm{Au}-$ gust The dust resides in a well-mixed layer about $2 \mathrm{~km}$ thick (between 1 to $3 \mathrm{~km}$ in altitude) as it advects west and enters the Caribbean Sea on 23 August Colarco et al. (2003b) found a similar layer over the Caribbean but located between 3 to $5 \mathrm{~km}$ in altitude during the Puerto Rico Dust Experiment (June-July 2000).

The descent of the Saharan dust layers during transport was recognized previously by Colarco et al. (2003b) who suggested it was due partly to particle sedimentation. On the other hand, Doherty et al. (2008) suggested the descent is dominated by vertical air motions. The Sahara Air Layer (SAL) is affected by the Azores High. The Azores High usu- ally extends westward from the Azores toward Bermuda. It becomes stronger and moves north toward the Iberian Peninsula in summer. Descending air in the Azores High will cause the top of the SAL to descend as air is transported to the Caribbean Sea from West Africa. The transport of dust in the SAL from West Africa to the Caribbean Sea took about one week (17 August to 25 August). The mean vertical velocity of the dust descent is about $6.3 \mathrm{~mm} \mathrm{~s}^{-1}$ based on the vertical extinction profiles of 17 August to 25 August 2006. Liu et al. (2008b) found that the mean descending velocity of the top of the Saharan dust layer is about $6 \mathrm{~mm} \mathrm{~s}^{-1}$ for transport from the west coast of Africa to the Caribbean Sea based on depolarization profiles for these same days in $\mathrm{Au}-$ gust 2006. The HYSPLIT model showed that the SAL descended between West Africa and the Caribbean Sea from 17 August to 27 August at about $4.0 \mathrm{~mm} \mathrm{~s}^{-1}$ (Fig. 11). The difference between the dust descent rate $\left(6.3 \mathrm{~mm} \mathrm{~s}^{-1}\right)$ and the air descent rate $\left(4.0 \mathrm{~mm} \mathrm{~s}^{-1}\right)$ is consistent with the fall velocity of dust particles around $2 \mu \mathrm{m}$ in size. Hence about one third of the descent rate of the dust is due to sedimentation and two thirds to the descent of the air in the case studied.

Figure 7 shows the map of CALIPSO tracks for Asian dust used in this study (7 May (most westerly track) to 10 May (most easterly track) of 2007). The asterisk and the cross marks indicate two dust transport paths for Asian dust from 7 May to 10 May of 2007. We averaged 120-laser shots from CALIPSO over about $40 \mathrm{~km}$ along the track both at the asterisk and cross mark points. The paths differ by the altitude of the dust layer. The track to the south was followed by dust below $3 \mathrm{~km}$, and the track to the north by dust above $3 \mathrm{~km}$. The transport paths are tracked by the HYSPLIT model. Vertical shear of the wind prevented a "SAL-like" layer from advecting away from the dust source.

The simulated dust vertical distribution of Asian dust is consistent with CALIPSO (lidar) retrievals (Fig. 12). Asian dust shows multiple layers (two layers in the case studied) during transport. One layer is at the altitudes between about $4.5-6.5 \mathrm{~km}$ (and is located to the north along the asterisks in Fig. 7) and shows little descent, while the other, lower layer top descends with time from $3 \mathrm{~km}$ on 7 May to $1 \mathrm{~km}$ on 9 May (there are no data available below $1 \mathrm{~km}$ on 10 May 2007). The HYSPLIT model showed that the air between $4.5-6.5 \mathrm{~km}$ ascended at about $0.4 \mathrm{~cm} \mathrm{~s}^{-1}$ during transport from 7 May to 10 May of 2007 along the CALIPSO tracks (Fig. 13). Such ascent is enough to compensate for the sedimentation of particles as large as 3-4 $\mu \mathrm{m}$. This ascent is consistent with the mid-latitude frontal cyclones, which not only generate dust storms, but also lift Asian dust into the upper troposphere and transport it along the westerly jet. The behavior of the upper and lower dust layers is consistent with results from Huang et al. (2008).

The magnitude of the vertical extinction for the higher layer decreases from $0.1 \mathrm{~km}^{-1}$ (averaged from the CALIPSO data) and $0.12 \mathrm{~km}^{-1}$ (averaged from the model) on 7 May to $0.04 \mathrm{~km}^{-1}$ (averaged from the CALIPSO data) and 

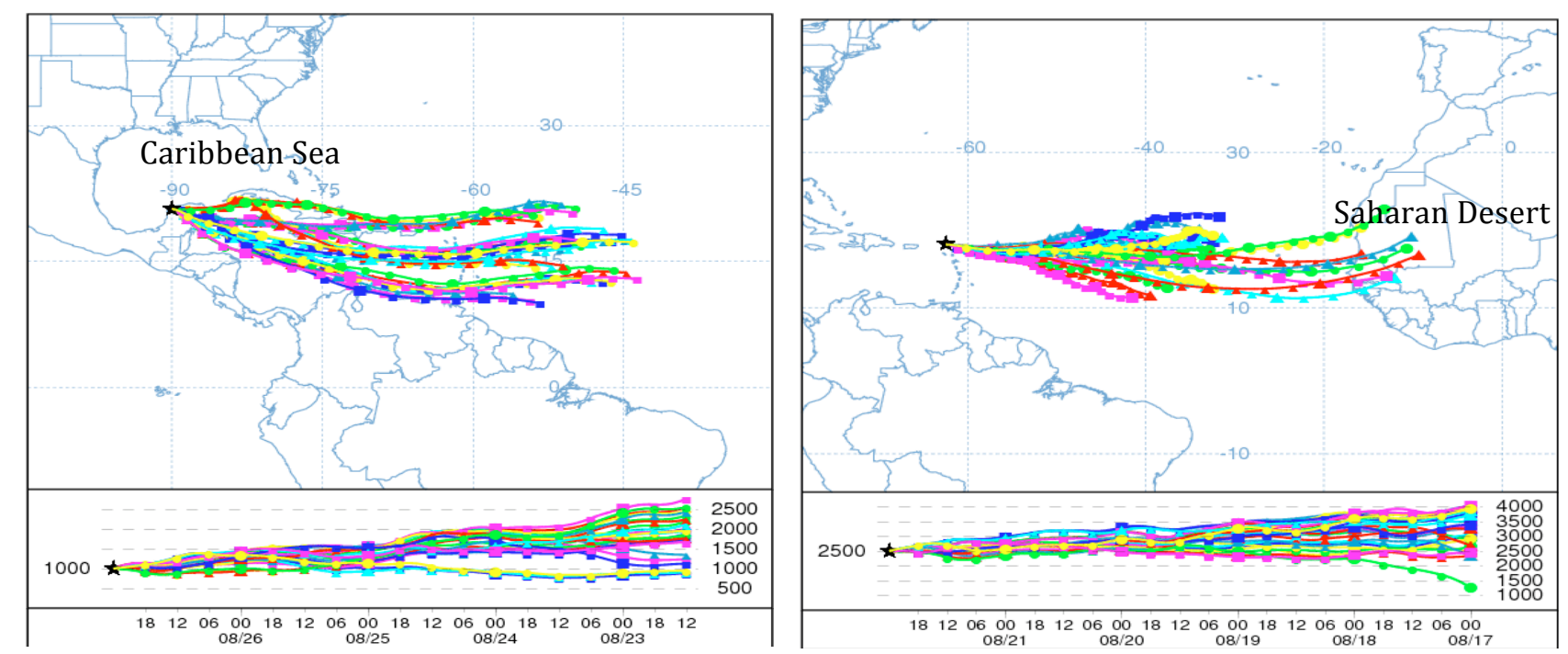

Fig. 11. Back trajectory ensemble of Sahara dust for Caribbean Sea from 27 August to 22 August in 2006 (left) and from 22 August to 17 August in 2006 (right) using HYSPLIT model for altitude $1000 \mathrm{~m}$ (left) and $2500 \mathrm{~m}$ (right). The horizontal trajectory components (top) and the vertical components (bottom) are shown in the figures. We chose two back trajectory ensemble runs because the maximum ensemble run time of HYSPLIT is $120 \mathrm{~h}$.

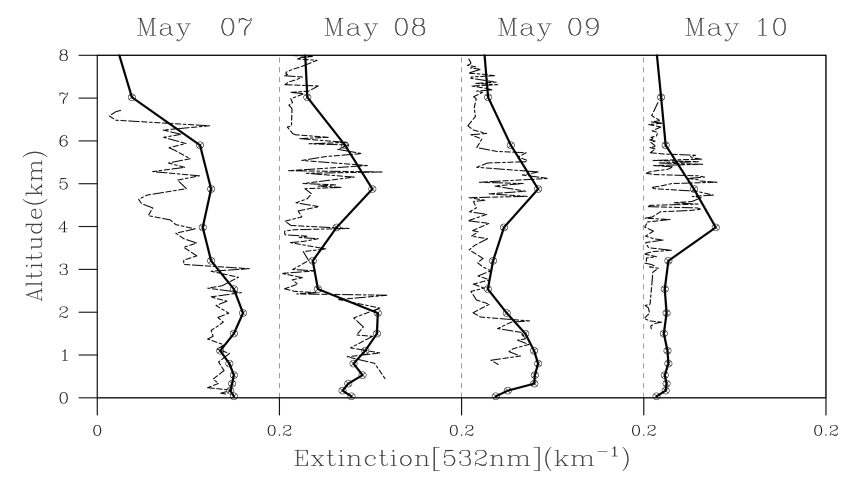

Fig. 12. Comparison of vertical distribution of Asian dust between model simulations and CALIPSO observations in May of 2007.

$0.05 \mathrm{~km}^{-1}$ (averaged from the model) on 10 May 2007. There is a larger magnitude change for the extinction in the lower dust layer, which changes from $0.135 \mathrm{~km}^{-1}$ (averaged from the CALIPSO data) and $0.15 \mathrm{~km}^{-1}$ (averaged from the model) on 7 May to 0 (averaged from the CALIPSO data) and $0.05 \mathrm{~km}^{-1}$ (averaged from the model) on 9 May 2007.

In conclusion we find the vertical distributions of Asian and African dust are different. African dust is in a deep layer, the SAL, which descends at about $6 \mathrm{~mm} \mathrm{~s}^{-1}$ as it crosses the Atlantic. Asian dust does not form a deep layer, but is split by vertical wind shear into two layers in the case studied. Unlike African dust, the top layer shows no evidence of descent during transport.

\subsection{Dust size distribution}

The dust size distribution can be important for optical properties such as the wavelength dependence of the optical depth, and the single scattering albedo. Small particles $(0.1$ to $1.0 \mu \mathrm{m}$ diameter) have larger scattering and absorbing cross sections per unit mass than large particles (Seinfeld and Pandis, 1998). We would like to know if Saharan and Asian dust particles have similar or different size distributions.

Figure 14 shows the 532-nm volume depolarization ratio from Saharan dust (around $15.02^{\circ} \mathrm{N}, 6.90^{\circ} \mathrm{W}$ ) measured by CALIPSO on 21 July which goes near the AERONET site at Dakar. The dust fills the SAL from the ground to about $6 \mathrm{~km}$ altitude. There are cirrus clouds around $10^{\circ} \mathrm{N}, 8^{\circ} \mathrm{W}$ at 11 to $14 \mathrm{~km}$ altitudes that are distinguished from dust by their height and the fact that the lidar beam is almost totally attenuated beneath the cirrus. The volume depolarization ratio is computed from the total attenuated backscatter in the CALIPSO version 1 data products following Cairo et al. (1999) and Liu et al. (2008):

$\delta(r)=\frac{\beta_{532, \mathrm{~m}, \perp}(r)+\beta_{532, \mathrm{p}, \perp}(r)}{\beta_{532, \mathrm{~m}, \|}(r)+\beta_{532, \mathrm{p}, \|}(r)}$

Where $\beta_{532, \mathrm{~m}, \perp}(r)$ and $\beta_{532, \mathrm{p}, \perp}(r)$ are the components of the backscatter signal polarized perpendicular to the polarization plane of the linearly polarized laser pulse due to the molecular scattering and particulate scattering at range $r$ and at the laser wavelength $532 \mathrm{~nm}$, respectively. $\beta_{532, \mathrm{~m}, \|}(r)$ and $\beta_{532, \mathrm{p}, \|}(r)$ are the components of the backscatter signal polarized parallel to the polarization plane of the linearly polarized laser pulse due to the molecular scattering 


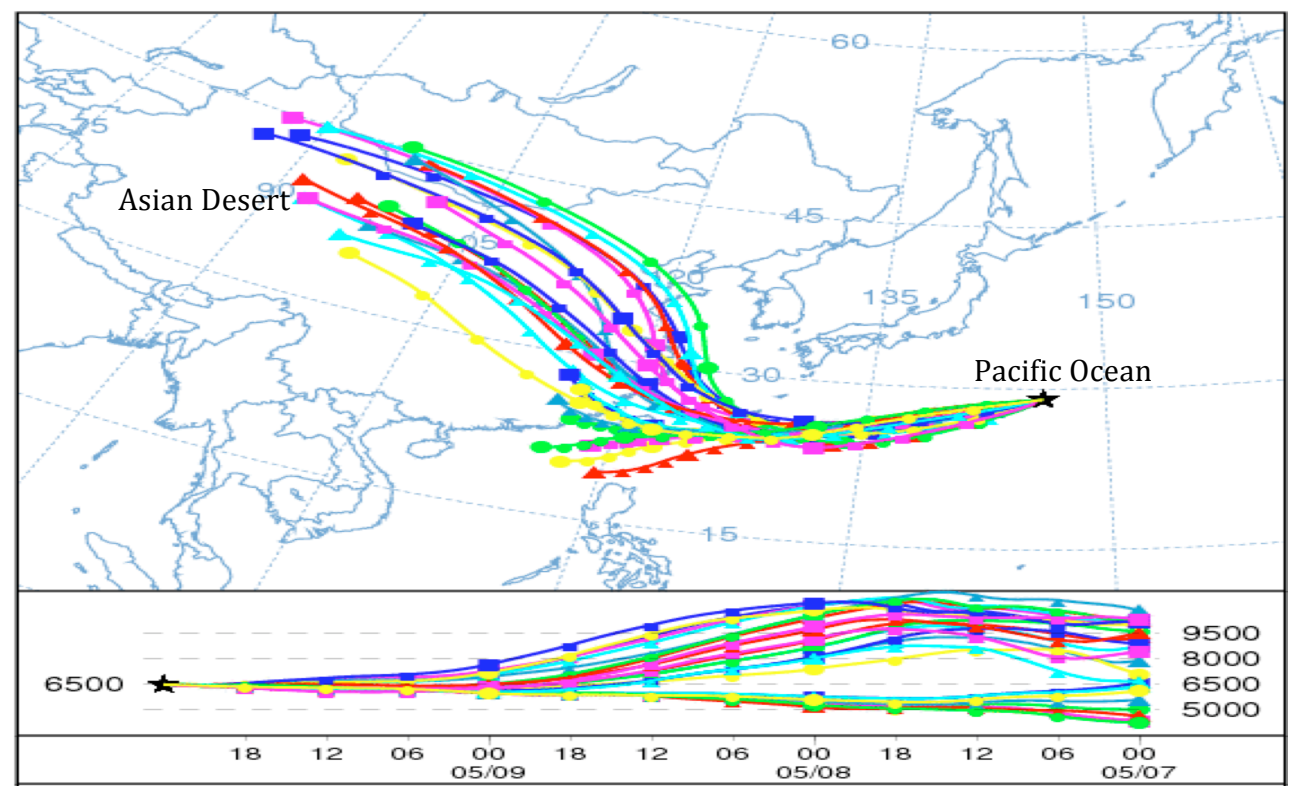

Fig. 13. Back trajectory ensemble of Asian dust for Pacific Ocean from 10 May to 7 May 2007 using HYSPLIT model for altitude 6500 m. The horizontal trajectory components (top) and the vertical components (bottom) are shown in the figure. Note the back trajectory goes from right (the black star at Pacific Ocean) to left (Asian Desert) (top) and it goes from left (the black star at $6500 \mathrm{~m}$ ) to right (multiple levels) (bottom).

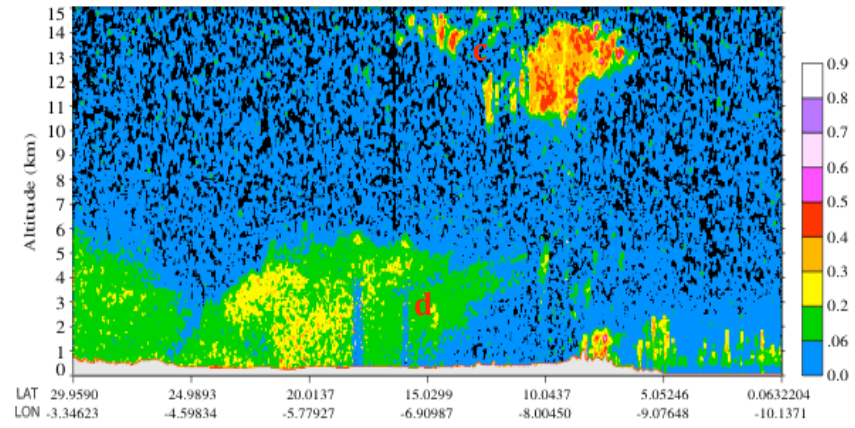

Fig. 14. The 532-nm depolarization ratio for Saharan dust on 21 July 2007. Red characters "c" and "d" represent "clouds layers" and "dust plumes", respectively.

and particulate scattering at range $r$ and the laser wavelength $532 \mathrm{~nm}$, respectively. The values of the volume depolarization ratio of dust aerosols are usually between 0.06 to 0.3 , whereas the ratio is below 0.06 (close to zero) for other aerosol types (Liu et al., 2008). The relatively high values of the dust depolarization ratios are due to the nonsphericity and large size of dust particles.

Figure 15 shows the dust depolarization profile for Asian dust on 23 May 2007. Dust extends to about 8 kilometers over the Gobi Deserts (between $45.0254^{\circ} \mathrm{N}, 109.356^{\circ} \mathrm{E}$ and $40.0556^{\circ} \mathrm{N}, 107.684^{\circ} \mathrm{E}$ ) on 23 May 2007 , but does not make a continuous layer to the surface.

We compare the dust size distributions between Saharan and Asian dust during dust outbreaks. Considering the

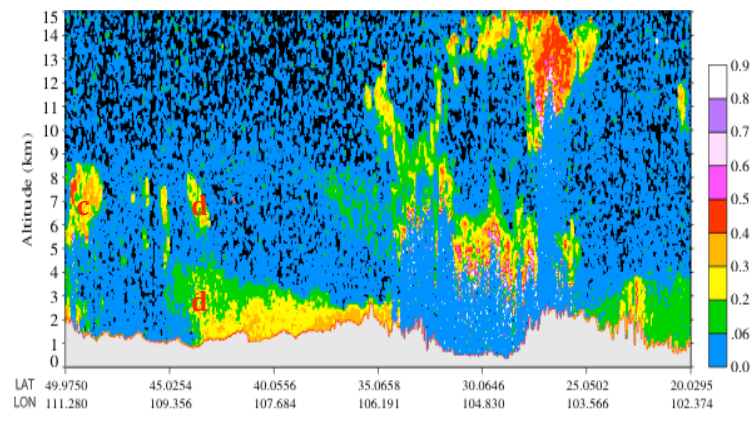

Fig. 15. The 532-nm depolarization ratio for Asian dust on 23 May 2007. Red characters "c" and "d" represent "clouds layers" and "dust plumes", respectively.

availability of AERONET observations, we choose Dakar on 22 July 2007 and Xianghe on 24 May 2007, which are close to dust sources, to represent Saharan and Asian dust, respectively.

Figures 16 and 17 present the modeled volume size distribution of Saharan dust at Dakar and the modeled volume size distribution of Asian dust at Xianghe, respectively. The model simulations are compared to AERONET measurements in each figure. The AERONET and modeled size distribution for Saharan dust in Fig. 16 show only one mode located near $1.0 \mu \mathrm{m}$ for dust with radius larger than about $0.2 \mu \mathrm{m}$. The AERONET and modeled size distributions for Asian dust (Fig. 17) shows two volume modes, one near $0.5 \mu \mathrm{m}$ and one near $2 \mu \mathrm{m}$ radius. It is interesting 


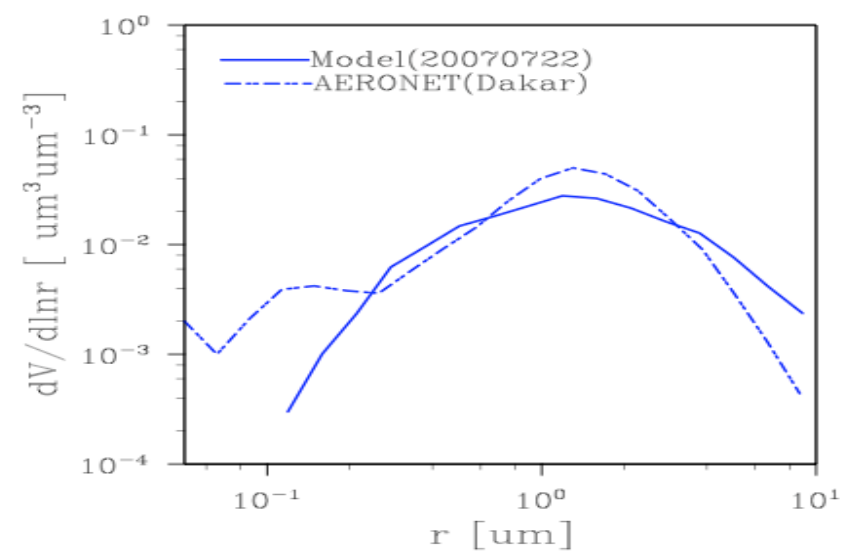

Fig. 16. Modeled volume size distribution of Saharan dust in Dakar $\left(14.39^{\circ} \mathrm{N}, 16.95^{\circ} \mathrm{W}\right)$ constrained by AERONET measurements.

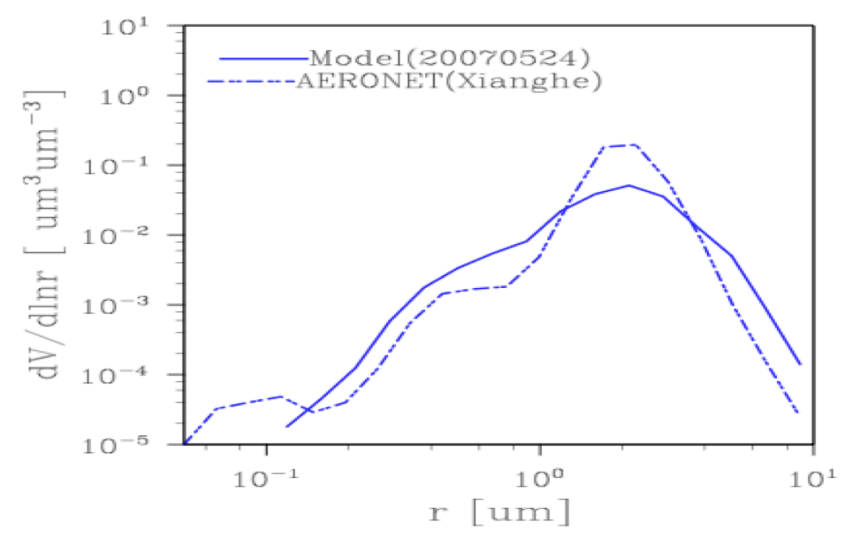

Fig. 17. Modeled volume size distribution of Asian dust in Xianghe $\left(39.75^{\circ} \mathrm{N}, 116.96^{\circ} \mathrm{E}\right)$ constrained by AERONET measurements.

that the model reproduces both of these distributions even though it uses identical dust source functions in each case. These volume mode radii have been verified by previous field campaigns both in Asia and in Sahara. McNaughton et al. (2009) indicated that the mode volume radius of the Asian dust is around $2 \mu \mathrm{m}$ radius based on the analysis from insitu sampling of tropospheric aerosol during spring of 2006 in Phase B of the Intercontinental Chemical Transport Experiment (INTEX-B). Nowottnick et al. (2010) also found that the mode volume radius of Saharan dust is around 1 micron radius based on sampling during the African Monsoon Multidisciplinary Analyses field campaign (AugustSeptember 2006). It should be noted that there are fine mode particles (such as nitrate, sulfate, and black carbon) in the AERONET size distribution data in Figs. 16 and 17 (mode around $0.1 \mu \mathrm{m}$ ), but such particles have not been included in our model.

We suggest that the reason for the different numbers of size modes and the different mode radius values between African and Asian dust is related to the difference in mixing and in vertical ascent of the dust in the atmosphere. Over the Sahara there is strong mixing throughout the deep mixed layer. Hence, while particles larger than about $1 \mu \mathrm{m}$ are influenced by sedimentation, the remainder are well mixed so the size distribution is relatively unimodal. Over Asia, the mixing occurs only in a shallow layer, and there is some ascent in the cyclonic circulation which lifts the dust. Hence the size distribution is modified as particles larger than about $2 \mu \mathrm{m}$ are able to fall against ascending air but smaller ones are not able to be removed by sedimentation.

We conclude that the particle size distributions in Saharan and Asian dust advected away from the sources likely differ, but these differences can be modeled using the same set of dust lifting functions. The differences are not related to surface mineralology or lifting rates, but rather to different vertical velocities and turbulent mixing rates during transport.

\subsection{Single scattering albedo}

Figure 18 compares of the single scattering albedo between the model simulations and the AERONET retrievals both for Asian (Gobi) Desert (Dalanzadgad (43.3 $\left.{ }^{\circ} \mathrm{N}, 104.3^{\circ} \mathrm{E}\right)$ ) in April 2006 and the Sahara Desert (Tamanrasset_TMP $\left.\left(22.5^{\circ} \mathrm{N}, 5.3^{\circ} \mathrm{E}\right)\right)$ in July 2006 . We choose these two locations and time periods because they are close to the dust sources (while Dakar and Xianghe which we analyzed for size distributions are downwind of dust sources), which minimize potential effects from air pollution, and also have cloud-screened and quality-assured AERONET data. Unfortunately size distributions retrieved from the AERONET data were not available for these sites on these days.

For the model, we assume the real part of the complex refractive index (assumed to be 1.55) is independent of wavelength both for Asian dust and Saharan dust based on the AERONET retrievals (Dubovik et al., 2000; Lyamani et al., 2005) and previous studies (Patterson et al., 1977; Diaz et al., 2000; Liu et al., 2002). We use data on the imaginary part of the refractive index from AERONET site measurements at the dust source regions that should be dominated by relative pure mineral dust particles. In downwind regions other pollutants such as nitrate, sulfate, and black carbon may alter the single scattering albedo. The imaginary part of the dust refractive index is constrained by the averaged AERONET value in April of 2006 at Dalanzadgad $(0.0027,0.0022,0.0017,0.0013$ with increasing wavelength at $440 \mathrm{~nm}, 670 \mathrm{~nm}, 870 \mathrm{~nm}$, and $1020 \mathrm{~nm}$, respectively) for Asian dust and in July of 2006 at Tamanrasset_TMP $(0.0036,0.0031,0.0026,0.0020$ with increasing wavelength at $440 \mathrm{~nm}, 670 \mathrm{~nm}, 870 \mathrm{~nm}$, and $1020 \mathrm{~nm}$, respectively) for Saharan dust. Figure 18 shows that the averaged single scattering albedo is larger for Asian dust than the Saharan dust. This is consistent with previous work suggesting that the dust transported from Asia to the Pacific may not absorb as much light as the dust from the Sahara Desert 

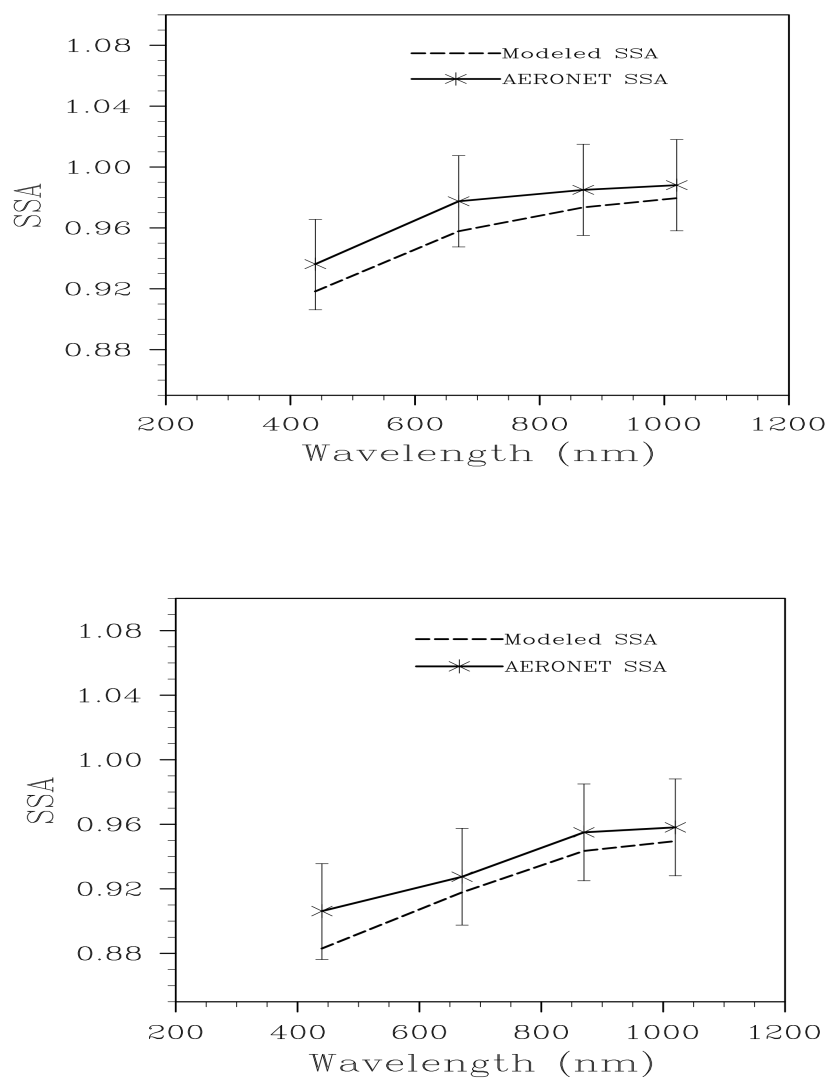

Fig. 18. The comparison of the single scattering albedo between the model simulations and the AERONET retrievals both for Asia Deserts (top) (Dalanzadgad $\left(43.3^{\circ} \mathrm{N}, 104.3^{\circ} \mathrm{E}\right)$ in April 2006) and Sahara Deserts (bottom) (Tamanrasset_TMP $\left(22.5^{\circ} \mathrm{N}, 5.3^{\circ} \mathrm{E}\right)$ in July 2006).

(Sokolik and Toon, 1999). The Asian dust has a smaller imaginary refractive index than Saharan dust, which is main reason the Asian dust has a higher single scattering albedo near the source. The single scattering albedos may depend on size as well, particularly as the size distributions are modified downwind of the sources as discussed previously. It should be noted that some studies report much lower SSA values of Asian dust that in Fig. 18 (Pandithurai et al., 2008, Ge et al., 2010). The small SSA values ranging from 0.74 to 0.84 at $500 \mathrm{~nm}$ reported by Pandithurai et al. (2008) originated from New Delhi, India, where dust is likely mixed with absorbing anthropogenic aerosols. The Zhangye site studied in Ge et al. (2010) is the center of the Hexi Corridor in China, which is $618 \mathrm{~km}$ to the south of Dalanzadgad. The small SSA values ranging from 0.76 to 0.86 between $415 \mathrm{~nm}$ to $870 \mathrm{~nm}$ in Zhangye reported by Ge et al. (2010) may also be explained by the local pollution.

\section{Summary and conclusions}

Using our model we find that the yearly annual dust flux from Africa is about 3 times greater than that from Asia. In general, it is observed that the dust optical depth is higher over the Atlantic than over the Pacific at similar downwind distances from the two dust sources. The monthly-averaged optical depth is 0.382 and 0.339 over the Pacific at Osaka in May 2007 for AERONET data and model simulation, respectively. However, the monthly-averaged optical depth is 0.613 and 0.579 over Atlantic at Capo Verde in July 2007 for AERONET data and model simulation, respectively. Hence even during peak months for dust lifting in Asia, smaller dust optical depths occur than during peak months in Africa.

The annual dust flux near the dust source is about $1088 \mathrm{Tg} \mathrm{yr}^{-1}$ across $10^{\circ} \mathrm{W}\left(10^{\circ} \mathrm{S}-40^{\circ} \mathrm{N}, 10^{\circ} \mathrm{W}\right)$ and $355 \mathrm{Tg} \mathrm{yr}^{-1}$ across $105^{\circ} \mathrm{E}\left(25^{\circ} \mathrm{N}-55^{\circ} \mathrm{N}, 105^{\circ} \mathrm{E}\right)$ for $\mathrm{Sa}-$ hara and Asia in 2007, respectively. Saharan deserts are largely south of $30^{\circ} \mathrm{N}$, while Asian ones are primarily north of $30^{\circ} \mathrm{N}$. This leads them to experience different meteorological regimes. Saharan dust lifting occurs all year long, primarily due to subtropical weather systems. The Saharan dust transport into the Caribbean is controlled primarily by a semi- permanent high, the Azores High. Dust lifting from African dust sources can be triggered and modulated by synoptic systems, such as African easterly waves. The dust outbreaks usually occur within the ridge region of passing easterly waves with a period of 5-7 days. In contrast, $45 \%$ of Asian dust was lifted in spring during the modeled year of 2007 when mid-latitude frontal systems lead to high winds. The seasonal variation of dust outbreaks in Asia is associated with the seasonal modulation of the wind speed. Strong winds occur most frequently in spring in Asia due to the activity of the mid-latitude frontal systems. The midlatitude frontal cyclones associated with intense cold fronts from Mongolia to northeastern China not only generate dust storms, but can also lift Asian dust into the westerly jet in the upper troposphere.

Rainfall is more abundant over Asia during the dust lifting events than over the Sahara, leading to greater local dust removal than over the Sahara. However, wet removal is a small fraction of the total removal of dust, and removal processes do not account for the difference in annual dust flux between the Sahara and Asia. Instead, the Sahara simply has about three times as much area with dust lifting as Asia because Asia has smaller deserts and also more vegetation and snow cover, which suppresses dust lifting.

During the major lifting season the power averaged winds over Africa and Asia are similar. However in other seasons Africa has stronger winds than does Asia, which further contributes to more dust lifting over Africa. The power-averaged wind contributes about a factor of 1.7 to the differences of the total dust fluxes between the two sources averaged over the year. 
The vertical distribution of Asian and African dust also differs in the cases we considered. The Saharan dust is primarily located in a deep layer, the SAL. The top of the layer descends during transport, which we conclude is mainly due to descending air in the Azores High. There are two noticeable layers of Asian dust during transport in May. One layer stays well above boundary layer, and does not descend with time. The other dust layer is in a shallow near surface boundary layer and descends with time. The transport of Asian dust is dominated by the westerlies at high altitudes, while it is controlled by regional weather systems and topography at lower altitudes. Sedimentation does not seem to play a significant role in the descent of long lasting layers. Horizontal wind shear can also play a role in creating elevated dust layers by moving dust horizontally, which is particularly important over Asia.

The size distribution of Asian dust (at Xianghe) is bimodal while that of Saharan dust (at Dakar) is uni-modal. The volume size distribution of Asian dust peaks around 2 microns, whereas it peaks around 1 micron for Saharan dust. Both model simulations and the AERONET retrievals show similar patterns. We suggest these differences originate from mixing in the boundary layers, and the vertical winds that occur during transport. For the case we studied, winds over Africa were descending in a well-mixed deep boundary layer, while those over Asia were ascending and there was no deep boundary layer. The ascending winds may have strong enough to loft micron sized dust.

We assume the real part of the complex refractive index is independent of wavelength (1.55) both for Asian dust and Saharan dust based on the AERONET retrievals and previous studies. We use data on the imaginary part of the refractive index from AERONET site measurements near the dust source regions. We find that the average single scattering albedo is larger for Asian dust than the Saharan dust. This is consistent with the refractive indecies inferred by AERONET for the two dust sources, and with a previous study that the dust transported from Asia to the Pacific may not absorb as much light as the dust from the Sahara. As the size distribution evolves downwind of the sources due to the vertical winds experienced during transport, and as pollutants are added to the dust, the single scattering albedos will evolve.

Acknowledgements. Lin Su was partly supported by the NASA Earth and Space Science Fellowship Program-Grant 10-Earth10R10. NSF grant ATM - 0856007 also supported this work as did the CALIPSO science team under NN07AR13G. The CALIPSO program data were obtained from the NASA Langley Research Center Atmospheric Science Data Center. We thank AERONET staff for establishing and maintaining the sites used in this investigation of the AERONET data. We also acknowledge Z. Liu, P. R. Colarco, A. Gettelman, and X. Liu for helpful discussion. We gratefully thank the reviewers for their valuable time and helpful suggestions.

Edited by: Q. Fu

\section{References}

Ackerman, A. S., Hobbs, P. V., and Toon, O. B.: A model for particle microphysics, turbulent mixing, and radiative transfer in the stratocumulus-topped marine boundary layer and comparisons with measurements, J. Atmos. Sci., 52, 1204-1236, 1995.

Arellano Jr., A. F., Raeder, K., Anderson, J. L., Hess, P. G., Emmons, L. K., Edwards, D. P., Pfister, G. G., Campos, T. L., and Sachse, G. W.: Evaluating model performance of an ensemblebased chemical data assimilation system during INTEX-B field mission, Atmos. Chem. Phys., 7, 5695-5710, doi:10.5194/acp7-5695-2007, 2007.

Barth, M. C., Rasch, P. J., Kiehl, J. T., Benkovitz, C. M., and Schwartz, S. E.: Sulfur chemistry in the National Center for Atmospheric Research Community Climate Model: Description, evaluation, features, and sensitivity to aqueous chemistry, J. Geophys. Res., 105, 1387-1415, 2000.

Betzer, P. R., Carder, K. L., Duce, R. A., Merrill, J. T., and Tindale, N. W.: Long-range transport of giant mineral aerosol particles, Nature, 336, 568-571, 1998.

Cairo, F., Donfrancesco, G., Adriani, A., Pulvirenti, L., and Fierli, F.: Comparison of Various Linear Depolarization Parameters Measured by Lidar, Appl. Opt., 38, 4425-4432, 1999.

Carmichael, G. R., Tang, Y., Kurata, G., Uno, I., Streets, D., Woo, J.-H., Huang, H., Yienger, J., Lefer, B., Shetter, R., Blake, D., Atlas, E., Fried, A., Apel, E., Eisele, F., Cantrell, C., Avery, M., Barrick, J., Sachse, G., Brune, W., Sandholm, S., Kondo, Y., Singh, H., Talbot, R., Bandy, A., Thorton, D., Clarke, A., and Heikes, B.: Regional-scale chemical transport modeling in support of intensive field experiments: Overview and analysis of the TRACE-P observations, J. Geophys. Res., 108(D21), 8823, doi:10.1029/2002JD003117, 2003.

Chin, M., Ginoux, P., Lucchesi, R., Huebert, B., Weber, E., Anderson, T., Masonis, S., Blomquist, B., Bandy, A., and Thornton, D.: A global aerosol model forecast for the ACEAsia field experiment, J. Geophys. Res., 108(D23), 8654, doi:10.1029/2003JD003642, 2003.

Chin, M., Chu, D. A., Levy, R., Remer, L. A., Kaufman, Y. J., Holben, B. N., Eck, T., and Ginoux, P.: Aerosol distribution in the Northern Hemisphere during ACE-Asia: Results from global model, satellite observations, and Sun photometer measurements, J. Geophys. Res., 109, D23S90, doi:10.1029/2004JD004829, 2004.

Clarke, A. D., Collins, W. G., Rasch, P. J., Kapustin, V. N., Moore, K., Howell, S., and Fuelberg, H. E.: Dust and pollution transport on global scales: Aerosol measurements and model predictions, J. Geophys. Res., 106, 32555-32569, 2001.

Colarco, P. R., Toon, O. B., Torres, O., and Rasch, P. J.: Determining the UV imaginary index of refraction of Saharan dust particles from Total Ozone Mapping Spectrometer data using a three-dimensional model of dust transport, J. Geophys. Res., 107(D16), 4312, doi:10.1029/2001JD000903, 2002.

Colarco, P. R., Toon, O. B., and Holben, B. N.: Saharan dust transport to the Caribbean during PRIDE: 1. Influence of dust sources and removal mechanisms on the timing and magnitude of downwind aerosol optical depth events from simulations of in situ and remote sensing observations, J. Geophys. Res., 108(D19), 8589, doi:10.1029/2002JD002658, 2003a.

Colarco, P. R., Toon, O. B., Reid, J. S., Livingston, J. M., Russell, P. B., Redemann, J., Schmid, B., Maring, H. B., Savoie, 
D., Welton, E. J., Campbell, J. R., Holben, B. N., and Levy, R.: Saharan dust transport to the Caribbean during PRIDE: 2. Transport, vertical profiles, and deposition in simulations of in situ and remote sensing observations, J. Geophys. Res., 108(D19), 8590, doi:10.1029/2002JD002659, 2003b.

Collins, W. D., Rasch, P. J., Boville, B. A., Hack, J. J., McCaa, J. R., Williamson, D. L., Kiehl, L. T., Briegleb, B., Bitz, C., Lin, S., Zhang, M., and Dai, Y.: Description of the NCAR Community Atmosphere Model (CAM3.0), Technical Report NCAR/TN464+STR, National Center for Atmospheric Research, Boulder, Colorado, 210 pp., 2004.

Cuesta, J., Marsham, J. H., and Parker, D. J.: Flamant C, Dynamical mechanisms controlling the vertical redistribution of dust and the thermodynamic structure of the West Saharan atmospheric boundary layer during summer, Atmos. Sci. Lett., 10, 34-42, 2009.

Díaz, J. P., Exposito, F. J., Torres, C. J., Carreño, V., and Redondas, A.: Simulation of mineral dust effects on UV-radiation levels, J. Geophys. Res., 105, 4979-4991, 2000.

Doherty, O. M., Riemer, N., and Hameed, S.: Saharan mineral dust transport into the Caribbean: Observed atmospheric controls and trends, J. Geophys. Res., 113, D07211, doi:10.1029/2007JD009171, 2008.

Draxler, R. R. and Rolph, G. D.: HYSPLIT (Hybrid SingleParticle Lagrangian Integrated Trajectory) model, Air Resour. Lab., NOAA, Silver Spring, Md. (available at: http://www.arl. noaa.gov/ready/hysplit4.html), 2003.

Dubovik, O., Smirnov, A., Holben, B. N., King, M. D., Kaufman, Y. J., and Slutsker, I.: Accuracy assessments of aerosol optical properties retrieved from AERONET sun and sky radiance measurements, J. Geophys. Res., 105, 9791-9806, 2000.

Duce, R.: The atmospheric input of trace species to the world ocean, Global Biogeochem. Cycle, 5, 193-259, 1991.

Duce, R. A., Unni, C. K., Ray, B. J., Prospero, J. M., and Merrill, J. T.: Long-range atmospheric transport of soil dust from Asia to the tropical North Pacific: temporal variability, Science, 209, 1522-1524, 1980.

Dunion, J. P. and Velden, C. S.: The impact of Saharan air layer on Atlantic tropical cyclone activity, Bull. Am. Meteorol. Soc., 85, 353-365, doi:10.1175/BAMS-85-3-353, 2004

Nowottnick, E., Colarco, P., Ferrare, R., Chen, G., Ismail, S., Anderson, B., and Browell, E.: Online simulations of mineral dust aerosol distributions: Comparisons to NAMMA observations and sensitivity to dust emission parameterization, J. Geophys. Res., 115, D03202, doi:10.1029/2009JD012692, 2010.

Eguchi, K., Uno, I., Yumimoto, K., Takemura, T., Shimizu, A., Sugimoto, N., and Liu, Z.: Trans-pacific dust transport: integrated analysis of NASA/CALIPSO and a global aerosol transport model, Atmos. Chem. Phys., 9, 3137-3145, doi:10.5194/acp-93137-2009, 2009.

Fernald, F. G.: Analysis of atmospheric lidar observations: some comments, Appl. Opt., 23, 652-653, 1984.

Fernald, F. G., Herman, B. M., and Reagan, J. A.: Determination of aerosol height distributions by lidar, Journal of Atmospheric Meteorology, 11, 482-489, 1972.

Ge, J., Su, J., Ackerman, T. P., Fu, Q., Huang, J., and Shi, J.: Dust aerosol optical properties retrieval and radiative forcing over northwestern China during the 2008 ChinaU.S joint field experiment, J. Geophys. Res., 115, D00K12,
doi:10.1029/2009JD013263, 2010.

Gillette, D. A. and Passi, R.: Modeling dust emission caused by wind erosion, J. Geophys. Res., 93, 14233-14242, 1988.

Gomes, L., Bergametti, G., Coud'e-Gaussen, G., and Rognon, P.: Submicron desert dusts: A sandblasting process, J. Geophys. Res., 95, 13927-13935, 1990.

Gong, S. L., Zhang, X. Y., Zhao, T. L., McKendry, I. G., Jaffe, D. A., and Lu, N. M.: Characterization of soil dust aerosol in China and its transport and distribution during 2001 ACE-Asia: 2. Model simulation and validation, J. Geophys. Res., 108(D9), 4262, doi:10.1029/2002JD002633, 2003.

Generoso, S., Bey, I., Labonne, M., and Bréon, F. M.: Aerosol vertical distribution in dust outflow over the Atlantic: Comparisons between GEOS-Chem and Cloud-Aerosol Lidar and Infrared Pathfinder Satellite Observation (CALIPSO), J. Geophys. Res., 113, D24209, doi:10.1029/2008JD010154, 2008.

Ginoux, P., Chin, M., Tegen, I., Prospero, J. M., Holben, B., Dubovik, O., and Lin, S. J.:Sources and distributions of dust aerosols simulated with the GOCART model. J. Geophys. Res., 106, 20255-20273, 2001.

Grousset, F. E., Ginoux, P., Bory, A., and Biscaye, P. E.: Case study of a Chinese dust pume reaching the French Alps., Geophys. Res. Lett., 30, 1277, doi:10.029/2002/g1016833, 2003.

Haywood, J. M., Allan, R. P., Culverwell, I., Slingo, A., Milton, S. F., Edwards, J. M., and Clerbaux, N.: Can desert dust explain the outgoing longwave radition anomaly over the Sahara during July 2003?, J. Geophys. Res.-Atmos., 110, D05105, doi:10.1029/2004JD005232, 2005.

Haywood, J. M., Pelon, J., Formenti, P., Bharmal, N., Brooks, M., Capes, G., Chazette, P., Chou. C., Christopher, S., Coe, H., Cuesta, J., Derimian, Y., Desboeufs, K., Greed, G., Harrison, M., Heese, B., Highwood, E. J., Johnson, B., Mallet, M., Marticorena, B., Marsham, J., Milton, S., Myhre, G., Osborne, S. R., Parker, D. J., Rajot, J. -L., Schulz, M., Slingo, A., Tanre, D., and Tulet, P.: Overview of the Dust and Biomass-burning Experiment and African Monsoon Multidisciplinary Analysis Special Observing Period-0, J. Geophys. Res., 113, D00C17, doi:10.1029/2008JD010077, 2008.

Heese, B. and Wiegner, M.: Vertical aerosol profiles from Raman polarization lidar observations during the dry season AMMA field campaign, J. Geophys. Res., 113, D00C11, doi:10.1029/2007JD009487, 2008.

Heintzenberg, J.: The SAMUM-1 experiment over Southern Morocco: overview and introduction, Tellus, 61, 2-11, doi:10.1111/j.1600-0889.2008.00403.x, 2008.

Holben, B. N., Eck, T. F., Slutsker, I., Tanreacute;, D., Buis, J. P., Setzer, A., Vermote, E. F., Reagan, J. A., Kaufman, Y. J., Nakajima, T., Lavenu, F., Jankowiak, I., and Smirnov, A.: AERONETA federated instrument network and data archive for aerosol characterization, Remote Sens. Environ., 66, 1-16, 1998.

Huang, J., Minnis, P., Yi, Y., Tang, Q., Wang, X., Hu, Y., Liu, Z., Ayers, K., Trepte, C., and Winker, D.: Summer dust aerosols detected from CALIPSO over the Tibetan Plateau, Geophys. Res. Lett., 34, L18805, doi:10.1029/2007GL029938, 2007.

Huang, J., Minnis, P., Chen, B., Huang, Z., Liu, Z., Zhao, Q., Yi, Y., and Ayers, J. K.: Long-range transport and vertical structure of Asian dust from CALIPSO and surface measurements during PACDEX, J. Geophys. Res., 113, D23212, doi:10.1029/2008JD010620, 2008. 
Huang, J., Fu, Q., Su, J., Tang, Q., Minnis, P., Hu, Y., Yi, Y., and Zhao, Q.: Taklimakan dust aerosol radiative heating derived from CALIPSO observations using the Fu-Liou radiation model with CERES constraints, Atmos. Chem. Phys., 9, 4011-4021, doi:10.5194/acp-9-4011-2009, 2009.

Huebert, B. J., Bates, T., Russell, P. B., Shi, G., Kim, Y., Kawamura, K., Carmichael, G., and Nakajima, T.: An overview of ACEAsia: Strategies for quantifying the relationships between Asian aerosols and their climatic impacts, J. Geophys. Res., 108(D23), 8633, doi:10.1029/2003JD003550, 2003.

Husar, R. B., Tratt, D. M., Schichtel, B. A., Falke, S. R., Li, F., Jaffe, D., Gasso, S., Gill, T., Laulainen, N. S., Lu, F., Reheis, M. C., Chun, Y., Westphal, D., Holben, B. N., Gueymard, C., McKendry, I., Kuring, N., Feldman, G. C., McClain, C., Frouin, R. J., Merrill, J., DuBois, D., Vignola, F., Murayama, T., Nickovic, S., Wilson, W. E., Sassen, K., Sugimoto, N., and Malm, W. C.: Asian dust events of April 1998, J. Geophys. Res., 106, 18317-18330, 2001.

IPCC, Climate Change: The Physical Science Basis, Contribution of Working Group 1 to the Fourth Assessment Report of the Intergovernmental Panel On Climate Change, edited by: Solomon, S., Qin, D., Manning, M., Chen, Z., Marquis, M., Averyt, K. B., Tignor, M., and Miller, H. L., Cambridge University Press, Cambridge, United Kingdom and New York, NY, USA, 2007.

Jacob, D. J., Crawford, J. H., Kleb, M. M., Connors, V. S., Bendura, R. J., Raper, J. L., Sachse, G. W., Gille, J. C., Emmons, L., and Heald, C. L.: Transport and Chemical Evolution Over the Pacific (TRACE-P) aircraft mission: Design, execution, and first results, J. Geophys. Res., 108(D20), 9000, doi:10.1029/2002JD003276, 2003.

Jensen, E. J., Toon, O. B., Westphal, D. L., Kinne, S., and Heymsfield, A. J.: Microphysical modeling of cirrus: 1.Comparison with 1986 FIRE IFO measurements, J. Geophys. Res., 99, 10421-10442, 1994.

Jones, C., Mahowald, N, and Luo, C.: The role of easterly waves on African desert dust transport, J. Clim., 16(22), 3617-3628, 2003.

Karyampudi, V. M., Palm, S. P., Reagen, J. A., Fang, H., Grant, W. B., Hoff, R. M., Moulin, C., Pierce, H. F., Torres, O., Browell, E. V., and Melfi, S. H.: Validation of the Saharan dust plume conceptual model using lidar, Meteosat, and ECMWF data, Bull. Am. Meteorol. Soc., 80, 1045-1075, 1999.

Kaufman, Y. J. and Fraser, R. S.: The effect of smoke particles on cloud and climate forcing, Science, 277, 1636-1639, 1997.

Kaufman, Y. J., Tanre, D., Dubovik, O., Karnieli, A., and Remer, L. A.: Absorption of sunlight by dust as Inferred from satellite and ground-based remote sensing, Geophys. Res. Lett., 28, 14791483, 2001.

Kistler, R., Kalnay, E., Collins, W., Saha, S., White, G., Woollen, J., Chelliah, M., Ebisuzaki, W., Kanamitsu, M., Kousky, V., van den Dool, H., Jenne, R., and Fiorino, M.: The NCEP-NCAR 50-year reanalysis: monthly means CD-ROM and documentation, Bull. Amer. Meteor. Soc., 82(2), 247-267, 2001.

Knippertz, P., Deutscher, C., Kandler, K., Muller, T., Schulz, O., and Schutz, L.: Dust mobilization due to density currents in the Atlas region: Observations from the Saharan Mineral Dust Experiment 2006 field campaign, J. Geophys. Res., 112, D21109, doi:10.1029/2007JD008774, 2007.

Laurent, B., Marticorena, B., Bergametti, G., and Mei, F.: Modeling mineral dust emissions from Chinese and Mongolian deserts,
Global Planet. Change, 52, 121-141, 2006.

Lee, E.-H. and Sohn, B.-J.: Examining the impact of wind and surface vegetation on the Asian dust occurrence over three classified source regions, J. Geophys. Res., 114, D06205, doi:10.1029/2008JD010687, 2009.

Lin, S.-J. and Rood, R. B. : Multidimensional FluxForm Semi-Lagrangian Transport Schemes, Mon. Weather Rev., 124(9), 2046-2070, doi:10.1175/15200493(1996)124¡2046:MFFSLT ¿2.0.CO;2, 1996.

Liu, D., Wang, Z., Liu, Z., Winker, D., and Trepte, C.: A height resolved global view of dust aerosols from the first year CALIPSO lidar measurements, J. Geophys. Res., 113, D16214, doi:10.1029/2007JD009776, 2008.

Liu, Z., Sugimoto, N., and Murayama, T.: Extinction-to-backscatter ratio of Asian dust observed by high-spectral- resolution lidar and Raman lidar, Appl. Opt., 41, 2760-2767, 2002.

Liu, Z., Hunt, W., Vaughan, M., Hostetler, C., McGill, M., Powell, K., Winker, D., and Hu, Y.: Estimating random errors due to shot noise in backscatter lidar observations, Appl. Opt., 45, 44374447, 2006.

Liu, Z., Liu, D., Huang, J., Vaughan, M., Uno, I., Sugimoto, N., Kittaka, C., Trepte, C., Wang, Z., Hostetler, C., and Winker, D.: Airborne dust distributions over the Tibetan Plateau and surrounding areas derived from the first year of CALIPSO lidar observations, Atmos. Chem. Phys., 8, 5045-5060, doi:10.5194/acp-85045-2008, 2008a.

Liu, Z., Omar, A., Vaughan, M., Hair, J., Kittaka, C., Hu, Y., Powell, K., Trepte, C., Winker, D., Hostetler, C., Ferrare, R., and Pierce, R.: CALIPSO lidar observations of the optical properties of Saharan dust: A case study of long-range transport. J. Geophys. Res., 113, D07207, doi:10.1029/2007JD008878, 2008b.

Lyamani ,H., Olmo, F. J., and Alados-Arboledas, L.: Saharan dust outbreak over southeastern Spain as detected by sun photometer, Atmos. Environ., 39(38), 7276-7284, 2005.

Mahowald, N., Kohfeld, K., Hansson, M., Balkanski, Y., Harrison, S. P., Printice, I. C., Schulz, M., and Rodhe, H.: Dust sources and deposition during the last glacial maximum and current climate: a comparison of model results with paleodata from ice cores and marine sediments, J. Geophys. Res., 104, 15895-15916, 1999.

Mahowald, N., Yoshioka, M., Collins, W., Conley, A., Fillmore, D., and Coleman, D.: Climate response and radiative forcing from mineral aerosols during the glacial maximum, pre- industrial, current and doubled-carbon dioxide climates, Geophys. Res. Lett., 33, L20705, doi:10.1029/2006GL026126, 2006.

Maring, H., Savoie, D. L., Izaguirre, M. A., and Custals, L.: Vertical distributions of dust and sea salt over Puerto Rico during PRIDE measured from a light aircraft, J. Geophys., 108, 8587, doi:10.1029/2002JD002544, 2003.

Marsham, J. H., Parker, D. J., Grams, C. M., Johnson, B. T., Grey, W. M. F., and Ross, A. N.: Observations of mesoscale and boundary-layer scale circulations affecting dust transport and uplift over the Sahara, Atmos. Chem. Phys., 8, 6979-6993, doi:10.5194/acp-8-6979-2008, 2008.

Marticorena, B., Bergametti, G., Aumont, B., Callot, Y., N'Doum'e, C., and Legrand, M.: Modeling the atmospheric dust cycle: 2. Simulation of Saharan dust sources, J. Geophys. Res., 102, 4387-4404, doi:10.1029/96JD02964, 1997.

Marticorena, B. and Bergametti, G.: Modeling the atmospheric dust cycle: 1 . Design of a soil-derived dust emission scheme, J. Geo- 
phys. Res., 100(D8), 16415-16430, doi:10.1029/95JD00690, 1995.

Martin, J. H.: Testing the iron hypothesis in ecosystem of the equatorial Pacific Ocean, Nature, 371, 123-129, 1994.

McKendry, I. G., Macdonald, A. M., Leaitch, W. R., van Donkelaar, A., Zhang, Q., Duck, T., and Martin, R. V.: Trans-Pacific dust events observed at Whistler, British Columbia during INTEXB, Atmos. Chem. Phys., 8, 6297-6307, doi:10.5194/acp-8-62972008, 2008.

McNaughton, C. S., Clarke, A. D., Kapustin, V., Shinozuka, Y., Howell, S. G., Anderson, B. E., Winstead, E., Dibb, J., Scheuer, E., Cohen, R. C., Wooldridge, P., Perring, A., Huey, L. G., Kim, S., Jimenez, J. L., Dunlea, E. J., DeCarlo, P. F., Wennberg, P. O., Crounse, J. D., Weinheimer, A. J., and Flocke, F.: Observations of heterogeneous reactions between Asian pollution and mineral dust over the Eastern North Pacific during INTEX-B, Atmos. Chem. Phys., 9, 8283-8308, doi:10.5194/acp-9-8283-2009, 2009.

Mller, D., Heinold, B., Tesche, M., Tegen, I., Althausen, D., Arboledas, L. A., Amiridis, V., Amodeo, A., Ansmann, A., Balis, D., Comeron, A., D’Amico, G., Gerasopoulos, E., GuerreroRascado, J. L., Freudenthaler, V., Giannakaki, E., Heese, B., Iarlori, M., Knippertz, P., Mamouri, R. E., Mona, L., Papayannis, A., Pappalardo, G., Perrone, R.-M., Pisani, G., Rizi, V., Sicard, M., Spinelli, N., Tafuro, A., and Wiegner, M.: EARLINET observations of the 14-22-May long-range dust transport event during SAMUM 2006: validation of results from dust transport modeling, Tellus, 61(1), 325-339, doi:10.1111/j.16000889.2008.00400.x, 2008.

Osborne, S. R., Johnson, B. T., Haywood, J. M., Baran, A. J., Harrison, M. A. J., and McConnell, C. L.: Physical and optical properties of mineral dust aerosol during the Dust and Biomass-burning Experiment, J. Geophys. Res., 113, D00C03, doi:10.1029/2007JD009551, 2008.

Pandithurai, G., Dipu, S., Dani, K. K., Tiwari, S., Bisht, D. S., Devara, P. C. S., and Pinker, R. T.: Aerosol radiative forcing during dust events over New Delhi, India, J. Geophys. Res., 113, D13209, doi:10.1029/2008JD009804, 2008.

Patterson, E. M., Gillette, D., and Stockton, B. H.: Complex index of refraction between 300 and $700 \mathrm{~nm}$ for Saharan aerosols, J. Geophys. Res., 82, 3153-3160, 1997.

Pfister, L., Selkirk, H. B., Starr, D. O., Rosenlof, K., and Newman, P. A.: A meteorological overview of the TC4 mission, J. Geophys. Res., 115, D00J12, doi:10.1029/2009JD013316, 2010.

Prospero, J.: The atmospheric transport of particles to the ocean, in Particle Flux in the Ocean, 18-152, John Wiley, New York, 1996.

Prospero, J.: Long-term measurements of the transport of African mineral dust to the southeastern United States: Implications for regional air quality, J. Geophys. Res., 104, 15917-15927, 1999.

Prospero, J. M. and Carlson, T. N.: Vertical and areal distribution of Saharan dust over the western equatorial North Atlantic ocean, J. Geophys. Res., 77, 5255-5265, 1972.

Prospero, J. and Carlson, T.: Saharan air outbreaks over the tropical North Atlantic, Pure Appl. Geophys., 119, 677-691, 1981.

Prupacher, H.R. and Klett, J. D.: Microphysics of Clouds and Precipitation, Kluwer Academic Publishers, ISBN 9780792344094, 976 pp., 1996.

Rajot, J. L., Formenti, P., Alfaro, S., Desboeufs, K, Chevaillier, S.,
Chatenet, B., Gaudichet, A., Journet, E., Marticorena, B., Triquet, S., Maman, A., Mouget, N., and Zakou, A.: AMMA dust experiment: An overview of measurements performed during the dry season special observation period (SOP0) at the Banizoumbou (Niger) supersite, J. Geophys. Res., 113, D00C14, doi:10.1029/2008JD009906, 2008.

Ramanathan, V., Crutzen, P. J., Lelieveld, J., Mitra, A. P., Althausen, D., Anderson, J., Andreae, M. O., Cantrell, W., Cass, G. R., Chung, C. E., Clarke, A. D., Coakley, J. A., Collins, W. D., Conant, W. C., Dulac, F., Heintzenberg, J., Heymsfield, A. J., Holben, B., Howell, S., Hudson, J., Jayaraman, A., Kiehl, J. T., Krishnamurti, T. N., Lubin, D., McFarquhar, G., Novakov, T., Ogren, J. A., Podgorny, I. A., Prather, K., Priestley, K., Prospero, J. M., Quinn, P. K., Rajeev, K., Rasch, P., and Rupert, S., Sadourny, R., Satheesh, S. K., Shaw, G. E., Sheridan, P., and Valero, F. P. J.: The Indian Ocean Experiment: An integrated assessment of the climate forcing and effects of the great Indo-Asian haze, J. Geophys. Res., 106(D22), 28371-28399, doi:10.1029/2001JD900133, 2001.

Rasch, P. J., Collins, W. D., and Eaton, B. E.: Understanding the Indian Ocean Experiment (INDOX) aerosol distributions with an aerosol assimilation, J. Geophys. Res., 106, 7337-7355, 2001.

Rea, D. K., Leinen, M., and Janecek, T. R.: Geologic approach to the long-term history of atmospheric circulation, Science, 227, 721-725, 1985.

Reid, J. S., Westphal, D. L., Livingston, J. M., Savoie, D. L., Maring, H. B., Jonsson, H. H., Eleuterio, D. P., Kinney, J. E., and Reid, E. A.: Dust vertical distribution in the Caribbean during the Puerto Rico Dust Experiment, Geophys. Res. Lett., 29(7), 1151, doi:10.1029/2001GL014092, 2002.

Reid, J. S., Kinney, J. E., Westphal, D. L., Holben, B. N., Welton, E. J., Tsay, S., Eleuterio, D. P., Campbell, J. R., Christopher, S. A., Colarco, P. R., Jonsson, H. H., Livingston, J. M., Maring, H. B., Meier, M. L., Pilewskie, P., Prospero, J. M., Reid, E. A., Remer, L. A., Russell, P. B., Savoie, D. L., Smirnov, A., and Tanré, D.: Analysis of measurements of Saharan dust by airborne and ground-based remote sensing methods during the Puerto Rico Dust Experiment (PRIDE), J. Geophys. Res., 108(D19), 8586, doi:10.1029/2002JD002493, 2003.

Sassen, K.: Lidar backscatter depolarization technique for cloud and aerosol research, in Light Scattering by Nonspherical Particles: Theory, Measurements, and Geophysical Applications, edited by: Mishchenko, M. L., Hovenier, J. W., and Travis, L. D.,393-416, Academic Press, San Diego, 2000.

Schulz, M., Balkanski, Y., Guelle, W., and Dulac, F.: Role of aerosol size distribution and Source location in a three dimensional simulation of a saharan dust episode tested against satellite derived optical thickness, J. Geophys. Res., 103, 10579-10592, 1998.

Seinfeld, J. H. and Pandis, S. N.: Atmospheric Chemistry and Physics: From Air Pollution to Climate Change, John Wiley \& Sons, 1998.

Seinfeld, J. H., Carmichael, G. R., Arimoto, R., Conant, W. C., Brechtel, F. J., Bates, T. S., Cahill, T. A., Clarke, A. D., Doherty, S. J., Flatau, P. J., Huebert, B. J., Kim, J., Markowicz, K. M., Quinn, P. K., Russell, L. M., Russell, P. B., Shimizu, A., Shinozuka, Y., Song, C. H., Tang Y., Uno, I., Vogelmann, A. M., Weber, R. J., Woo, J., and Zhang, Y.: ACE-ASIA Regional climatic and atmospheric chemical effects of Asian 
dust and pollution, Bull. Am. Meteorol. Soc., 85(3), 367-380, doi:10.1175/BAMS-85-3-367, 2004.

Shao, Y. and Dong, C. H.: A Review on East Asian Dust Storm Climate, Modelling and Mornitoring, Global Planet. Changes, 52, 1-22, 2006.

Shao, Y. and Lu, I.: A simple expression for wind erosion threshold friction velocity, J. Geophys. Res., 105, 22437-22443, 2000.

Shao, Y. and Raupach, M.: Effect of saltation bombardment by wind, J. Geophys. Res., 98, 12719-12726, 1993.

Shaw, G. E.: Transport of Asian Desert Aerosol to the Hawaiian Islands, J. Appl. Meteorol., 19, 1254-1259, 1980.

Shimizu, A., Sugimoto, N., Matsui, I., Arao, K., Uno, I., Murayama, T., Kagawa, N., Aoki, K., Uchiyama, A., and Yamazaki, A.: Continuous observations of Asian dust and other aerosols by polarization lidars in China and Japan during ACE-Asia, J. Geophys. Res., 109, D19S17, doi:10.1029/2002JD003253, 2004.

Shinn, E. A., Smith, J. M., Prospero, G. W., Betzer, P., Hayes, M. L., Garrison, V., and Barber, R. T.: African dust and the demise of Caribbean coral reefs, Geophys. Res. Lett., 27, 3029-3032, 2000.

Smirnov, A., Holben, B. N, Savoie, D., Prospero, J. M., Kaufmann, Y. J., Tanré, D., Eck, T. F., and Slutsker, I. S.: Relationship between column aerosol optical thickness and in situ ground based dust concentrations over Barbados, Geophys. Res. Lett., 27, 1643-1646, 2000.

Sokolik, I. N. and Toon, O. B.: Direct radiative forcing by anthropogenic airborne mineral aerosols, Nature, 381, 681-683, doi:10.1038/381681a0, 1996.

Sokolik, I. N. and Toon, O. B.: Incorporation of mineralogical composition into models of the radiative properties of mineral aerosol from UV to IR wavelengths, J. Geophys. Res., 104, 9423-9444, 1999.

Stith, J. L., Ramanathan, V., Cooper, W. A., Roberts, G. C., DeMott, P. J., Carmichael, G., Hatch, C. D., Adhikary, B., Twohy, C. H., Rogers, D. C., Baumgardner, D., Prenni, A. J., Campos, T., Gao, R., Anderson, J., and Feng, Y.: An overview of aircraft observations from the Pacific Dust Experiment campaign, J. Geophys. Res., 114, D05207, doi:10.1029/2008JD010924, 2009.

$\mathrm{Su}, \mathrm{L}$. and Toon, O. B.: Numerical simulations of Asian dust storms using a coupled climate-aerosol microphysical model, J. Geophys. Res., 114, D14202, doi:10.1029/2008JD010956, 2009.

Tegen, I. and Fung, I.: Modeling of mineral dust in the atmosphere: Sources, transport, and Optical thickness, J. Geophys. Res., 99, 22897-22914, 1994.

Toon, O. B.: African dust in Florida clouds, Nature, 424, 623-624, 2003.

Toon, O. B., Turco, R., Westphal, D., Malone, R., and Liu, M.: A multidimensional model for aerosols: Description of computational analogs, J. Atmos. Sci., 45, 2123-2143, doi:10.1175/15200469(1988)045;2123:AMMFAD ¿2.0.CO;2, 1988.

Tratt, D. M., Frouin, R. J., and Westphal, D. L.: April 1998 Asian dust event: A southern California perspective, J. Geophys. Res., 106(D16), 18371-18379, 2001.

Uno, I., Carmichael, G. R., Streets, D. G., Tang, Y., Yienger, J. J., Satake, S., Wang, Z., Woo, J., Guttikunda, S., Uematsu, M., Matsumoto, K., Tanimoto, H., Yoshioka, K., and Lida, T.: Regional chemical weather forecasting using CFORS: Analysis of surface observation at Japanese Island Station during the ACE-Asia experiment, J. Geophys. Res. 108(D23), 8668,
doi:10.1029/2002JD002845, 2002.

Uno, I., Satake, S., Carmichael, G. R., Tang, Y., Wang, Z., Takemura, T., Sugimoto, N., Shimizu, A., Murayama, T., Cahill, T. A., Cliff, S., Uematsu, M., Ohta., S., Quinn., P. K., and Bates, T. S.: Numerical study of Asian dust transport during the springtime of 2001 simulated with the Chemical Weather Forecasting System (CFORS) model, J. Geophys. Res., 109, D19S24, doi:10.1029/2003JD004222, 2004.

Uno, I., Harada, K., Satake, S., Hara, Y., and Wang, Z.: Meteorological Characteristics and dust distribution of the Tarim Basin simulated by the nesting RAMS/CFORS dust model, J. Meteorol. Soc. Jpn., 83A, 219-239, 2005.

Uno, I., Yumimoto, K., Shimizu, A., Hara, Y., Sugimoto, N., Wang, Z., Liu, Z., and Winker, D. M.: 3D structure of Asian dust transport revealed by CALIPSO lidar and a 4DVAR dust model, Geophys. Res. Lett., 35, L06803, doi:10.1029/2007GL032329, 2008.

Uno, I., Eguchi, K., Yumimoto, K., Takemura, T., Shimizu, A., Uematsu., M., Liu, Z., Wang, Z., Hara, Y., and Sugimoto, N.: Asian dust transported one full circuit around the globe, Nat. Geosci., 2, 557-560, doi:10.1038/ngeo583, 2009.

VanCuren, R. A.: Asian aerosols in North America: Extracting the chemical composition and mass concentration of the Asian continental aerosol plume from long-term aerosol records in the western United States, J. Geophys. Res., 108(D20), 4623, doi:10.1029/2003JD003459, 2003.

Westphal, D. L., Toon, O. B., and Carlson, T. N.: A twodimensional numerical investigation of the dynamics and microphysics of Saharan dust storms, J. Geophys. Res., 92, 30273049, 1987.

Winker, D. M., Pelon, J. R., and McCormick, M. P.: The CALIPSO mission: Spaceborne lidar for observation of aerosols and clouds, Proc. SPIE, 4893, 1-11, 2003.

Winker, D. M., Hunt, W. H., and McGill, M. J.: Initial performance assessment of CALIOP, Geophys. Res. Lett., 34, L19803, doi:10.1029/2007GL030135, 2007.

Winker, D. M., Pelon, J., Coakley, J. A., Ackerman, S. A., Charlson, R., Colarco, P. R., Flamant, p., Fu, Q., Hoff, R. M., Kittaka, C., Kubar,. T. L., Le Treut, H., MvCormick, M. p., Megie, G., Poople, L., Powell, K., Trepte, C., Vaughan, M. A., Wielicki, B. A.: The CALIPSO mission: a global 3D view of aerosols and clouds, Bull. Amer. Meteor. Soc., 91(9), 1211-1229, 2010.

$\mathrm{Wu}, \mathrm{L}$. : Impact of Saharan air layer on hurricane peak intensity, Geophys. Res. Lett., 34, L09802, doi:10.1029/2007GL029564, 2007.

Young, S., Winker, D., Vaughan, M., Hu, Y., and Kuehn, R.: Extinction Retrieval Algorithms, CALIOP algorithm theoretical basis document PC-SCI-202 Part 4, available at: http://www.calipso. larc.nasa.gov/resources/pdfs/PC-SCI-202_Part4_v1.0.pdf, 2008.

Zender, C. S., Huisheng, B., and Newman, D.: Mineral dust entrainment and Deposition (DEAD) model: Description and 1990s dust climatology, J. Geophys. Res., 108(D14) ,4416, doi:10.1029/2002JD002775, 2003a. 